\title{
EXPANDING ACCESS TO NICKOLAS MURAY'S CELEBRITY PORTRAITS: \\ CROSS CATALOGUING OF RICHARD AND RONAY MENSCHEL LIBRARY \\ MANUSCRIPT AND PHOTOGRAPHY COLLECTIONS AT GEORGE EASTMAN HOUSE
}

By

Aya Sato
Bachelor of Arts, Bishop's University, Quebec, 2011

An applied thesis project

presented to Ryerson University \&

George Eastman House International Museum of Photography and Film

$$
\begin{aligned}
& \text { in partial fulfillment of the } \\
& \text { requirements for the degree of } \\
& \text { Master of Arts } \\
& \text { in the program of }
\end{aligned}
$$

Photographic Preservation and Collections Management

Toronto, Ontario, Canada \& Rochester, New York, USA, 2014

(C) Aya Sato 2014 


\section{Author's Declaration for Electronic Submission of a Thesis}

I hereby declare that I am the sole author of this thesis. This is a true copy of the thesis, including any required final revisions, as accepted by my examiners.

I authorize Ryerson University and George Eastman House International Museum of Photography and Film to lend this thesis to other institutions or individuals for the purpose of scholarly research.

I further authorize Ryerson University and George Eastman House International Museum of Photography and Film to reproduce this thesis by photocopying or by other means, in total or in part, at the request of other institutions or individuals for the purpose of scholarly research.

I understand that my thesis may be made electronically available to the public. 


\title{
EXPANDING ACCESS TO NICKOLAS MURAY'S CELEBRITY PORTRAITS: \\ CROSS CATALOGUING OF RICHARD AND RONAY MENSCHEL LIBRARY MANUSCRIPT AND PHOTOGRAPHY COLLECTIONS AT GEORGE EASTMAN HOUSE
}

Master of Arts, 2014

Aya Sato

Photographic Preservation and Collections Management

Ryerson University and George Eastman House International Museum of Photography and Film

\begin{abstract}
This applied thesis project was undertaken to expand access to the photographer Nickolas Muray's (1892-1965) celebrity portraits by creating intellectual links between the Richard and Ronay Menschel Library Manuscript Collection and the Department of Photography (DOP) Collection held at George Eastman House International Museum of Photography and Film, Rochester, New York. The project consisted of two phases: (1) to create item-level descriptions for the published examples of Muray's celebrity portraits in the Library's Nickolas Muray Manuscript (Mss) Collection Boxes 125-126 Illustrations, and (2) to revise the DOP catalogue records for the corresponding photographic prints and negatives, and their variants from the same photographic sessions within the museum's collections management system, The Museum System (TMS). This paper outlines the methodologies behind the project and describes decisions made to expand access to Muray's celebrity materials in both the manuscript and photographic collections.
\end{abstract}




\section{Acknowledgements}

Foremost, I would like to express my sincere appreciation to my advisor and first reader, Jamie M. Allen, Associate Curator at George Eastman House. This thesis would not have been possible without her guidance, continuous support and encouragement during both the practical and writing phases of the entire process.

I would also like to thank my second reader, Rochester Institute of Technology (RIT) Archivist Becky Simmons, for her time and sharing her expertise in archiving with me.

I am also grateful to the following George Eastman House staff, without whose assistance this thesis would not have been completed:

Joe Struble, Collection Manager; Ross Knapper, Assistant Collection Manager; Susan Drexler, Reference Librarian/Cataloger; and William Green, Curatorial Assistant, for allowing me access to the Photography and Manuscript Collections and for their help and patience with my questions and concerns.

Barbara Galasso, George Eastman House Photographer, for photographing a large volume of the Nickolas Muray materials.

Jessica Johnston, Associate Director of the PPCM Program, for her assistance throughout.

Anna Michas-Bailey for our personal friendship and for her support.

I am also indebted to my thesis proofreader, Molly Tarbell, for having assisted me with writing.

I would also like to thank the staff at English Language Support at Ryerson University, especially the Senior English Language Specialist, Christopher Brierley, for his continuous support.

From the Ryerson University PPCM faculty, I am thankful to David Harris, Director of the program, and Jennifer Park, PPCM Graduate Program Assistant.

Last but not least, I would like to thank my PPCM classmates from Rochester, especially Darren Kinsman and Josephine Minhinnett, not only for their advice on writing but also for the laughter, friendship and academic debates they brought to me throughout. I would also like to thank Stephanie Desgroseillers for her technical advice on TMS and imaging. 
For my aunt, Michiko Hara, without whose support I would not be where I am today. 


\section{Table of Contents}

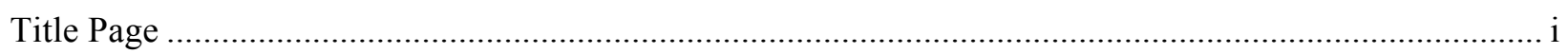

Author's Declaration for Electronic Submission of a Thesis ................................................................... ii

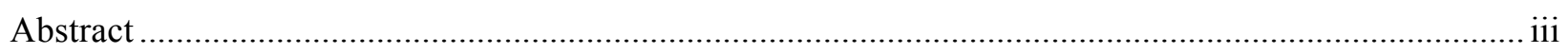

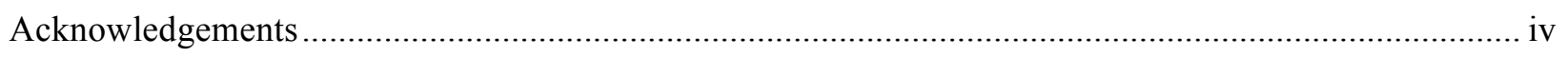

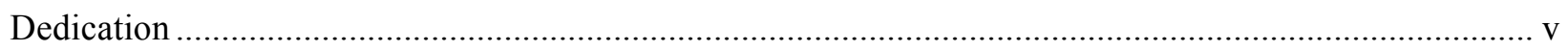

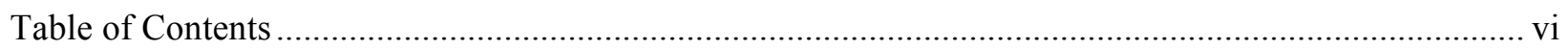

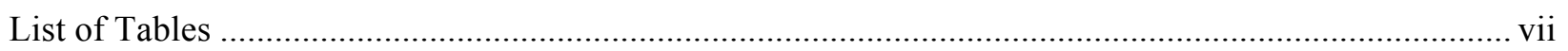

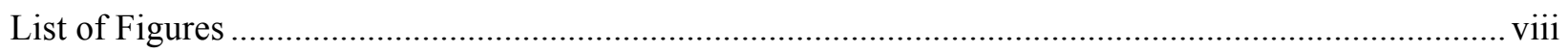

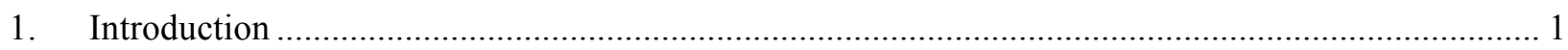

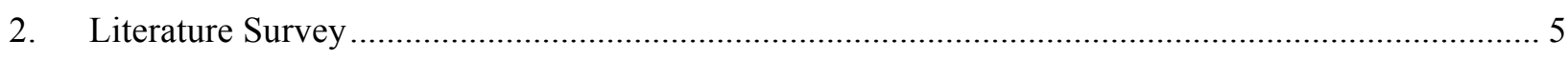

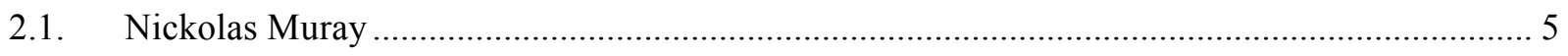

2.2. Expanding Access to Library Manuscript and Museum Collections ........................................ 8

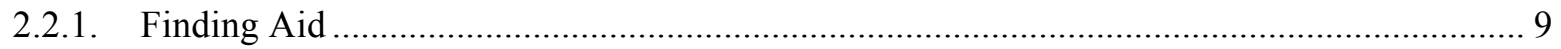

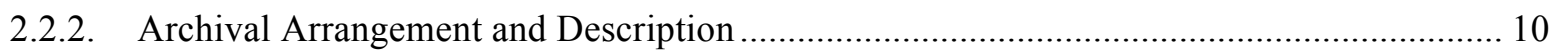

2.2.3. Museum Registration and Collections Management …............................................... 13

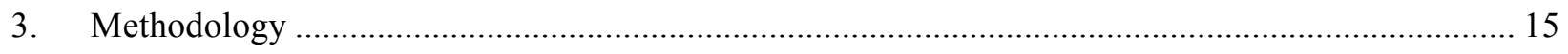

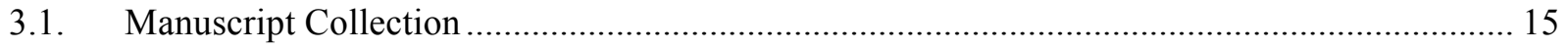

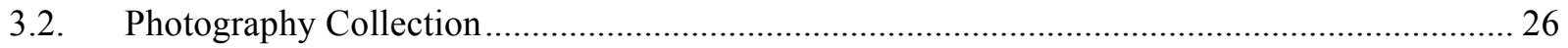

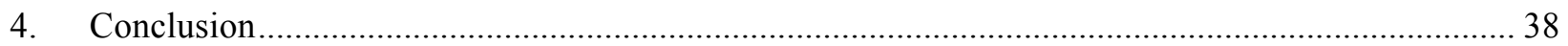

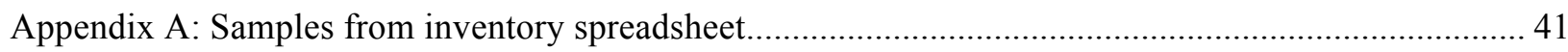

Appendix B: Samples from item-level descriptions for the Nickolas Muray Manuscript (Mss) Collection

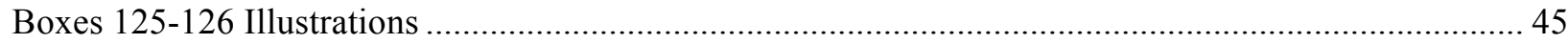

Appendix C: Samples of object-based The Museum System (TMS) catalogue records for the Department

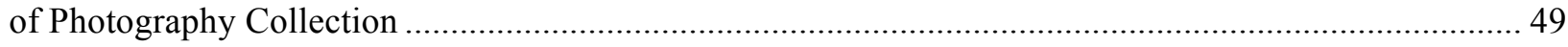

Appendix D: Flow chart for determining dates of production for Nickolas Muray's photographic prints

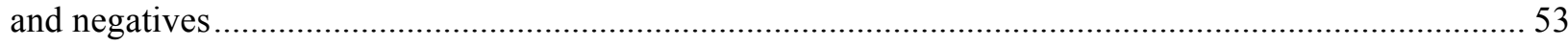

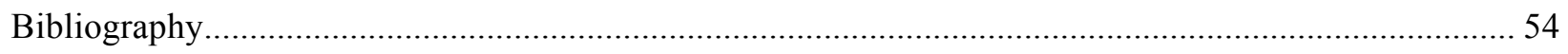




\section{List of Tables}

All Tables in this thesis are found in Appendix A.

Table 1. Sample from spreadsheet: scrapbooks

Table 2. Sample from spreadsheet: clippings and tear sheets

Table 3. Sample from spreadsheet: miscellaneous magazine periodicals

Table 4. Sample from spreadsheet: links between the Library manuscript materials and the Department of Photography Collection

Table 5. Sample from spreadsheet: links between related Library manuscript materials within the Mss Collection Boxes 125-126 


\section{List of Figures}

All photographs by Nickolas Muray reproduced in this thesis (C) Nickolas Muray Archives. Reproductions of the Nickolas Muray Manuscript (Mss) Collection and the Photography Collection, as well as images of processing the manuscript materials, are photographed by the George Eastman House Photographer, Barbara Galasso, and are courtesy of George Eastman House. Samples of the updated The Museum System (TMS) catalogue records are screen captures of the museum's TMS database (C) George Eastman House.

Figure 1. Whole-part hierarchy of the Nickolas Muray Manuscript (Mss) Collection..... 16

Figure 2. Samples of Muray's celebrity portraits, Nickolas Muray Mss Collection Box 125, Folder 1: Scrapbook 1, (Left) page 1 and (Right) page 18

Figure 3. Samples of Muray's commercial advertising works, Nickolas Muray Mss Collection, Box 126, Folder 14: Scrapbook 2, (Left) page 186 and (Right) page 220

Figure 4. Nickolas Muray Mss Collection Box 125, Folder 1: Scrapbook 1, page $21 \quad$.......................... 20

Figure 5. Vanity Fair 16, no. 4 (June 1921, page 55), Courtesy of Toronto Public Library .................... 20

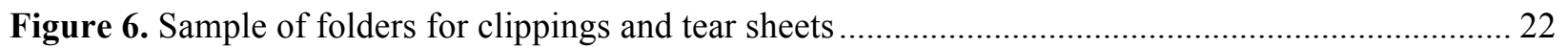

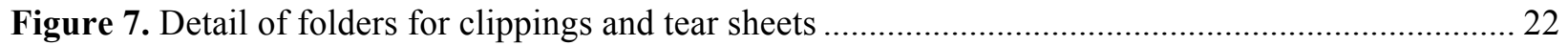

Figure 8. Sample of numbering clippings and tear sheets ............................................................... 23

Figure 9. Sample of numbering disassembled scrapbook pages ........................................................ 23

Figure 10. Overall organization of the Mss Collection Boxes 125-126 Nickolas Muray Illustrations ..... 24

Figure 11. Nickolas Muray Mss Collection Box 125, Folder 1: Scrapbook 1, page 23 ......................... 24

Figure 12. Nickolas Muray Mss Collection Box 125, Folder 4: Clippings and Tear Sheets, item 9........ 24

Figure 13. Nickolas Muray, Florence Reed, 1920. Gelatin silver print, 1977:0188:2318 _................... 26

Figure 14. Nickolas Muray, Hubert Stowitts-An American Dancer, ca. 1921. Negative, gelatin on

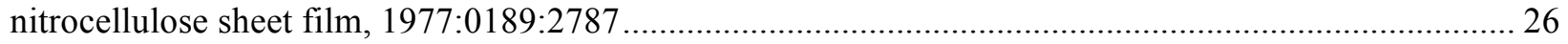

Figure 15. Nickolas Muray, Rose Rolando, ca. 1921. Gelatin silver print, 1977:0188:2398 .................. 27

Figure 16. Sample of updated Title field in TMS, 1977:0189:2787 ................................................. 29

Figure 17. Sample of updated Date field in TMS, 1977:0189:2787 ................................................. 31

Figure 18. Sample of updated Date field in TMS, 1977:0188:2318 ................................................ 32

Figure 19. Sample of updated Description field in TMS, 1977:0188:2398 …..................................... 34 
Figure 20. Before-and-after sample of the Related Works field in TMS, 1977:0188:2318 …............... 35

Figure 21. Sample of updated Notes field in TMS, 1977:0189:2787 ................................................. 36

Figure 22. Sample of updated Notes field in TMS, 1977:0188:2398 _.............................................. 37

Figure 23. Sample from item-level descriptions: Scrapbook 1 (Appendix B)..................................... 45

Figure 24. Sample from item-level descriptions: Clippings and Tear Sheets (Appendix B)................... 46

Figure 25. Sample from item-level descriptions: Miscellaneous Materials (Appendix B)...................... 47

Figure 26. Sample from item-level descriptions: Scrapbook 2 (Appendix B)..................................... 48

Figure 27. Sample of object-based TMS catalogue records: Dimension field (Appendix C) .................. 49

Figure 28. Sample of object-based TMS catalogue records: Inscription field (Appendix C).................. 50

Figure 29. Sample of object-based TMS catalogue records: Title on Object field (Appendix C)............ 51

Figure 30. Sample of object-based TMS catalogue records: Date field (Appendix C) ......................... 52 


\section{Introduction}

At one point, everybody who was anybody was being photographed by my father.

- Mimi Muray, daughter of Nickolas Muray and one of the directors of the Nickolas Muray Photography Archives ${ }^{1}$

The Hungarian photographer Nickolas Muray (born Miklós Mandl, February 15, 1892, Szeged, Hungary, died November 2, 1965, New York, New York) immigrated to the United States in 1913 and opened his first photography studio "Nickolas Muray, Character Portraiture" in 1920 in Greenwich Village, New York City. ${ }^{2}$ His 1920 photographic assignment with Harper's Bazar magazine, for which Muray photographed the Broadway star Florence Reed, marked the beginning of his career as a portrait photographer of magazines and newspapers. ${ }^{3}$ Between 1920 and 1932, Muray produced a large number of celebrity portraits for various mass-circulation magazines and newspapers, including Vanity Fair, Vogue, Harper's Bazar, Theatre Magazine, Motion Picture Magazine, Motion Picture Classic, Shadowland and The New York Times. ${ }^{4}$ Due to the craftsmanship of his work, Muray became well known for his iconic portraits of actors, authors, artists, dancers and other famous personalities. Not surprisingly, his reputation as a portraitist of celebrities corresponded to the popularity of Broadway shows and the emerging Hollywood motion picture industry in the 1920s United States—-the decade in which "fan"

1. Mimi Muray, foreword to Nickolas Muray: bir fotoğrafçinin portresi=Portrait of a Photographer, by Suna and Inan Kiraç Foundation, Pera Museum (Istanbul: Pera Museum Publication, 2013), 9.

2. Salomon Grimberg, "Nickolas Muray: Otoportre / self-portrait," in Nickolas Muray: bir fotoğrafçinin portresi $=$ Portrait of a Photographer, by Suna and Inan Kiraç Foundation, Pera Museum (Istanbul: Pera Museum Publication, 2013), 17; 20.

3. Ibid, 20. The portrait of Florence Reed is found in Haper's Bazar 55, no. 12 (December 1920, page 56). The magazine changed the spelling of its name to Harper's Bazaar in 1929.

4. It is important to define the term "celebrity portrait," as the distinctions between portraiture, theatre and fashion photography were often ambiguous in early magazine and newspaper illustrations. In this applied thesis, the term refers to both portraiture and theatre photography, including figure studies. However, it excludes Muray's commercial advertising works to which he shifted the focus of his photographic production in the 1930s, following the U.S. stock market crash on October 29, 1929. For more information on this shift in focus, see Salomon Grimberg, "Nickolas Muray: Otoportre / self-portrait," in Nickolas Muray: bir fotoğrafçinin portresi=Portrait of a Photographer, by Suna and Inan Kiraç Foundation, Pera Museum (Istanbul: Pera Museum Publication, 2013), 2122. 
magazines and newspapers played a large part in idolizing the theatre and film stars. ${ }^{5}$ Although Muray is celebrated for his mastery of the carbro colour process and for introducing natural colour photography into commercial advertising in 1931, knowledge of his earlier celebrity portraits is essential in order to fully appreciate this legendary photographer and his legacy. ${ }^{6}$

In 1970, Peggy (Margaret Schwab) Muray, Muray’s fourth wife, donated his photographic prints and negatives, as well as published examples of his photographs (in the forms of scrapbooks, clippings and tear sheets) to George Eastman House International Museum of Photography and Film, Rochester, New York. ${ }^{7}$ His children Mimi and Nicholas Christopher Muray and relative Gustav Schwab gifted additional relevant materials to the museum in $1974 .{ }^{8}$ Much, if not the majority, of the extensive collection of Muray's images at George Eastman House represents his celebrity portraits produced between 1920 and 1932. ${ }^{9}$ However, despite their similarity in the subject matter, his manuscript and photographic materials have hitherto been unrelated in their respective cataloguing systems. The Richard and Ronay Menschel Library at George Eastman House has adopted a system of archival description traditionally used by libraries and/or archives. Thus, the Library manages its manuscript collections

5. Paul Gallico, The Revealing Eye: Personalities of the 1920's in Photographs by Nickolas Muray and Words by Paul Gallico (New York: Atheneum, 1967), VIII-IX; Anthony Slide, "The Golden Age of the Fan Magazine," in Inside the Hollywood Fan Magazine (Jackson: University Press of Mississippi, 2010), 122; Kathleen Drowne and Patrick Huber, The 1920s (Westport, Connecticut: Greenwood Press, 2004), 222-224.

6. Ibid, 22. Muray's natural colour photograph was first reproduced on the cover of The Ladies' Home Journal in May 1931, for the feature of "First News of Summer Fashions from Paris."

7. George Eastman House acquisition records, Rochester, New York. Muray married his first wife, the Hungarian poet Illona Fulop, in 1916. After their divorce due to Fulop's adultery, he married his second wife, the Czechoslovakian dancer Leja Gorska, in 1922 and had his first daughter, Arija Muray. Following Arija's tragic death, however, Muray divorced Gorska and married Monica O'Shea in 1931. He divorced O'Shea in 1937 and married Peggy (Margaret Schwab) Muray on July 23, 1942. For a detailed biography of Nickolas Muray, see Suna and Inan Kiraç Foundation, Pera Museum, Nickolas Muray: bir fotoğrafçinin portresi=Portrait of a Photographer (Istanbul: Pera Museum Publication, 2013).

8. George Eastman House acquisition records, Rochester, New York.

9. George Eastman House holds a total of 25,527 works by Nickolas Muray-which constitute one of the largest collections at the museum. See Sheila J. Foster, Manfred Heiting and Rachel Stuhlman, Imagining Paradise: the Richard and Ronay Menschel Library at George Eastman House, Rochester (Göttingen: Steidl, 2007), 274.

In A History of Photography: From 1939 to the Present, Mulligan and Wooters further describe the content of the collection and write, "Most of the prints are black-and-white studio portraits of celebrities from the 1920s, when Muray maintained a studio in New York City's Greenwich Village." See Therese Mulligan and David Wooters, eds., A History of Photography: From 1839 to the Present; The George Eastman House Collection (Köln: Taschen, 2005), 554. 
through paper-based finding aids. In contrast, Muray's photographic prints and negatives held in the Department of Photography (DOP) Collection are catalogued using the museum's collections management system, The Museum System (TMS). Prior to this applied project, the Library finding aid for the Nickolas Muray Manuscript Collection provided minimal collection-level and box-level descriptions for the scrapbooks and related manuscript materials. Similarly, the existing DOP TMS catalogue records for Muray's photographic prints and negatives included only basic information, such as digital reproductions of the objects, descriptive titles, and approximate dates of production (for example, ca. 1922-1961).

The overarching goal of this applied project was to expand access to Muray's celebrity portraits by creating intellectual links between the Richard and Ronay Menschel Library Manuscript (Mss) Collection and the Department of Photography Collection at George Eastman House, which have up to now been managed by the two unrelated cataloguing systems (i.e., Library finding aid and DOP TMS catalogue records). To link the two systems, I first extended the existing Library finding aid for the Nickolas Muray Manuscript Collection and created item-level descriptions for the contents of two boxes of materials, namely, the Mss Collection Boxes 125-126 Nickolas Muray Illustrations (hereafter referred to as Mss Collection Boxes 125-126). Second, I revised the DOP TMS catalogue records for Muray's photographic prints and negatives - specifically, the ones with corresponding images to those found in the Mss Collection Boxes 125-126 and the variants from the same photographic sessions. In so doing, I aided the preservation of both materials by limiting their physical handling by future researchers.

This paper details the methodologies I followed in order to link the two systems and provides reasoning for the decisions I made in processing the manuscript and photographic collections, respectively. The chapter Literature Survey concentrates on 1) Nickolas Muray and his production of portrait photographs and 2) how the Richard and Ronay Menschel Library and the Department of Photography at George Eastman House — as well as libraries, archives, and museums at large — have historically managed their collections. The first Methodology section outlines how I inventoried and 
gathered information for Muray's celebrity materials in the Library's Manuscript Collection in order to create item-level descriptions for the Mss Collection Boxes 125-126. This section also demonstrates my understanding of archival arrangement and how I applied these concepts to increase the accessibility of the scrapbooks and related manuscript materials. The second Methodology section discusses in depth how DOP TMS catalogue fields—namely, Published Title, Date, Description, Related Works, and Notes - were used beyond the regular practice at George Eastman House to expand access not only to the DOP collection objects, but also to the corresponding images and their variants found in the Library's Mss Collection Boxes 125-126. Lastly, this paper concludes by suggesting that the methodologies adopted for this applied project can be extended to increase access to Muray's commercial advertising works also found in the Mss Collection Boxes 125-126 and the DOP Collection and includes my recommendations for future processing of these materials. 


\section{Literature Survey}

This literature survey was conducted in order to gain an understanding of Nickolas Muray as a portrait photographer, and to acquire knowledge of current approaches to the management of both library manuscript and museum collections. The first section reviews books, exhibition catalogues, and other texts that examine Muray's production of celebrity portraits during the 1920s and the early 1930s. The second section begins with a survey of three documents available at the Richard and Ronay Menschel Library: 1) the existing finding aid and 2) theses of two prior students that involved the creation of a finding aid for similar materials. This is followed by an investigation of general principles and practices of archival arrangement and description. The survey concludes by analyzing texts related to theories and practices of museum registration and collection management.

\subsection{Nickolas Muray}

An examination of existing literature on Nickolas Muray and his production of celebrity portraits during the 1920s and the early 1930s was essential in understanding the nature of the body of work for this applied project and establishing the rationale for cross-cataloguing Muray's manuscript and photographic materials. In practice, a survey of books and other publications with illustrations of Muray's celebrity portraits facilitated the identification of previously unidentified subjects in the scrapbooks and related manuscript materials.

Salomon Grimberg's "Nickolas Muray: Otoportre / Self-Portrait," in the exhibition catalogue Nickolas Muray: bir fotoğrafçinin portresi=Portrait of a Photographer, presents an in-depth biographical essay on the photographer. ${ }^{10}$ In this catalogue, Grimberg also compiles a detailed chronology of Muray's professional and personal life events. The catalogue places more emphasis on Muray's craftsmanship and

10. Suna and Inan Kiraç Foundation, Pera Museum, Nickolas Muray: bir fotoğrafçinin portresi=Portrait of a Photographer (Istanbul: Pera Museum Publication, 2013). 
creative modes of production as an "artist" portrait photographer rather than the original intent of his portraiture - that is, to appear on the pages of magazines and newspapers. ${ }^{11}$

The Revealing Eye: Personalities of the 1920's in Photographs by Nickolas Muray and Words by Paul Gallico examines Muray's celebrity portraits in relation to the social and cultural contexts of the 1920s. ${ }^{12}$ According to Gallico, the prevalence of "fan" magazines, motion pictures, radio and newspapers in the 1920s United States all resulted in the rise of celebrity culture. Marianne Fulton Margolis' introductory essay in Muray's Celebrity Portraits of the Twenties and Thirties: 135 Photographs by Nickolas Muray similarly suggests the social and cultural influences on Muray's celebrity portraits. ${ }^{13}$ As a historian of Alfred Stieglitz, Margolis further extends this notion and contextualizes Muray’s soft-focused and often-dramatic portraiture when she points out, "Of course, his work as a whole could not help being influenced by the most publicized twentieth-century trend in the art of photography: the Photo-Secession led by Alfred Stieglitz, which through its widely read quarterly Camera Work promoted pictorial photography." ${ }^{\prime 4}$ In relation to this applied thesis, Margolis briefly refers to Muray’s scrapbook clippings held, presumably, at George Eastman House; however, she merely considers the published examples of his fashion and commercial product works. ${ }^{15}$

Corser du Pont, in his thesis "Nickolas Muray: Environmental Portraiture, Vanity Fair" presented to Ryerson University and George Eastman House in 2010, speculates analytically about the production of Muray's environmental portraiture in relation to Vanity Fair magazine's subsequent use of his

11. The chapter "Portre Üzerine / On the Portrait" incorporates Muray's essay of the same title from 1923, in which he expresses his preference for pictorial portrait photography, achieved through the use of soft focus lens, short exposure time and retouching of negatives.

12. Paul Gallico, The Revealing Eye: Personalities of the 1920's in Photographs by Nickolas Muray and Words by Paul Gallico (New York: Atheneum, 1967).

13. Marianne Fulton Margolis, introduction to Muray's Celebrity Portraits of the Twenties and Thirties: 135 Photographs by Nickolas Muray (New York: Dover Publications, 1978).

14. Ibid.

15. Ibid. Marianne Fulton Margolis is the former Acting Curator of 20th Century Photography at George Eastman House. Muray's Celebrity Portraits of the Twenties and Thirties was published in association with the museum. 
photographs on its printed pages. ${ }^{16}$ This approach emphasizes the importance of cross-referencing Muray's photographic prints and negatives in his celebrity materials within DOP Collection with the photomechanical reproductions of the matching images and their variants found in Library's Mss Collection Boxes 125-126. Du Pont concludes his thesis by stating that the examination of Vanity Fair's subsequent use of Muray's environmental portraiture illustrates the photographer's "versatility, technical control, and creative vision."17

Dorothy Donnell's “The New Art of Camera Painting,” in the July 1920 issue of Shadowland magazine includes a description of his first studio in Greenwich Village:

On a crumbling six-panelled door on Macdougal Street, beside "Ye Silhouette Shoppe," a modest card announces Nickolas Muray, Character Portraiture, and up three flights of uncarpeted stairs in an attic studio, with no other aids than a whitewashed wall, a black velvet curtain, a green painted kitchen chair, this young Hungarian artist-photographer is making camera compositions that lift photography from the level of a mechanical trade to a place among the fine arts. ${ }^{18}$

Moreover, Donnell provides fresh insight into Muray's production of portrait photography when she reveals that not only did Muray participate in physiognomy classes, but he also "attended clinics at a Berlin hospital, watched operations, [and] visited morgues" in order to study anatomy and perfect the craft of his portraiture. ${ }^{19}$

Muray's interest in physical anatomy is also expressed in Heather Alberts' "The Figure as Sculptural Form." ${ }^{20}$ In this short text, the author specifically focuses on Muray's photographs of dancers and figure studies rather than discussing his celebrity portraits as a whole. Alberts writes, "Muray captured the intimate interaction between the dancer and the surrounding space, demonstrating his great

16. Corser Du Pont, "Nickolas Muray: Environmental Portraiture, Vanity Fair,” master's thesis, Ryerson University and George Eastman House International Museum of Photography and Film, 2010, http://digitalcommons.ryerson.ca/dissertations/1315.

17. Ibid, 62.

18. Dorothy Donnell, "The New Art of Camera Painting," Shadowland, July 1920, 15.

19. Ibid, 72.

20. Heather Alberts, "The Figure as Sculptural Form," 1983, George Eastman House Information File: Nickolas Muray, Richard and Ronay Menschel Library, Rochester, New York. 
understanding of choreographed movement as well as his love of the human form."21

The 1974 George Eastman House exhibition catalogue Nickolas Muray adheres to a short, archetypal biography of Muray both as a portrait and a commercial advertising photographer. ${ }^{22}$ This exhibition catalogue reveals that at least two examples of "Muray's scrapbook of reproductions" were included in the exhibition under the Biographical section. ${ }^{23}$

Finally, books such as Diana Edkins Richardson's ed. Vanity Fair: Photographs of an Age, 19141936, Graydon Carter's Vanity Fair, The Portraits: A Century of Iconic Images and Nathalie Herschdorfer's In Coming into Fashion: A Century of Photography at Condé Nast establish the contexts in which Muray worked as a magazine photographer. ${ }^{24}$ However, the majority of texts surveyed in relation to Muray's production of celebrity portraits emphasize his creative expression, craftsmanship and interest in human anatomy. They do not delve into the original intent of his portrait photographs - that is, they were made for hire to be reproduced on the pages of magazines and newspapers.

\subsection{Expanding Access to Library Manuscript and Museum Collections}

The overarching goal of both the Richard and Ronay Menschel Library and the Department of Photography (DOP) at George Eastman House is to ensure access to and preserve their collections, although the methods of collection management remain unique to their own traditions (i.e. through finding aids in the Library and with TMS catalogue records in the DOP). The literature survey in this section begins with a review of the existing finding aid for the Nickolas Muray manuscript materials held at the Library as well as prior students' theses that involved the creation of a finding aid for similar collections. This is followed by an examination of books and manuals that outline basic concepts and

21. Ibid.

22. Nickolas Muray. New York: International Museum of Photography at George Eastman House, 1974, published in conjunction with the exhibition of the same name, shown at the International Museum of Photography at George Eastman House in Rochester, New York.

23. Ibid.

24. Diana Edkins Richardson ed., Vanity Fair: Photographs of an Age, 1914-1936 (New York: Clarkson N. Potter, 1982); Graydon Carter, Vanity Fair, The Portraits: A Century of Iconic Images (New York: Abrams, 2008); Nathalie Herschdorfer, In Coming into Fashion: A Century of Photography at Condé Nast (Munich: Prestel, 2012). 
principles of archival arrangement and description. The survey concludes with an investigation of current texts about museum registration and collections management, on which the Department of Photography at George Eastman House bases its operation principles and collection management practice.

\subsubsection{Finding Aid}

The existing finding aid for the Nickolas Muray Manuscript Collection consists of minimal collection-level and box-level descriptions. ${ }^{25}$ A short biography of Muray found in the collection-level description focuses on his early photographic career in the 1920s. The section Provenance indicates that Muray's fourth wife, Peggy Muray, donated the scrapbooks and related manuscript materials for this applied project to George Eastman House in 1970, along with other miscellany associated with the photographer. The miscellany includes published articles on Muray and his work, miscellaneous printed materials, Muray's studio advertising, letter(s), typescripts (i.e., reviews of dance performances written by the photographer) and audio tapes. ${ }^{26}$ The box-level description reveals that the scrapbooks and the related materials in Boxes 125-126 account for the majority of the Nickolas Muray Manuscript Collection, while the miscellany listed above is stored together in Box 127.

Kristin E. Dudley’s finding aid “A Finding Aid for the Models' Guild of Philadelphia Papers” was created as the practical component of her applied thesis of the same title. ${ }^{27}$ Of many finding aids describing materials currently held in the Richard and Ronay Menschel Library, Dudley's finding aid specifically deals with a mixed collection of photographs and manuscript materials, thus setting an example for describing not only textual but also visual information. The fields of description for the photographs include subject, cross reference, quantity, description, dates identified, model identified,

25. Becky Simmons, "Nickolas Muray Manuscript Collection," finding aid, Richard and Ronay Menschel Library, George Eastman House International Museum of Photography and Film.

26. Audio tapes were donated later in 1974 by Muray's children, Mimi and Nicholas Christopher Muray.

27. Kristin E. Dudley, "A Finding Aid for the Models' Guild of Philadelphia Papers," master's thesis, Ryerson University and George Eastman House International Museum of Photography and Film, 2008. http://digitalcommons.ryerson.ca/dissertations/1086. 
shoot identified, photography studio and photographer identified, and supplemental notes. Although Dudley's finding aid provides only category-level descriptions for the photographs—such as by types of photograph (headshot, studio portrait, etc.), fashion styles and the actions being performed — it served as a model for extending the existing finding aid for the Nickolas Muray Manuscript Collection. Some of the descriptive fields listed above became a basis for the item-level descriptions of the Mss Collection Boxes 125-126.

The past master's thesis "Providing Access to the Everette Dixie Reese Prints and Negatives at the George Eastman House" was also consulted in search of literature on current standards in archival arrangement and description, and as an example of a finding aid that places an emphasis on these standards. ${ }^{28}$ Smith's finding aid is modeled after the Society of American Archivists' official content standard Describing Archives: A Content Standard (DACS), as well as examples from George Eastman House and the International Center of Photography in New York City. ${ }^{29}$ Additionally, the author acknowledges and bases her decisions on the archival theories outlined in Photographs: Archival Care and Management. ${ }^{30}$

\subsubsection{Archival Arrangement and Description}

Finding aids traditionally have been used as access tools in archives and for manuscript collections in libraries. Thus, an investigation of the concepts and principles of archival arrangement and description was deemed necessary. Although archival theory and practice did not explicitly apply to the updating of DOP TMS catalogue records for Muray's photographic prints and negatives, a survey of current literature on archiving was essential in creating intellectual links between the Library's Mss

28. Amanda L. Smith, "Providing Access to the Everette Dixie Reese Prints and Negatives at the George Eastman House," master's thesis, Ryerson University and George Eastman House International Museum of Photography and Film, 2011, http://digitalcommons.ryerson.ca/dissertations/1767.

29. Society of American Archivists, Describing Archives: A Content Standard, 2nd ed. (Chicago: Society of American Archivists, 2013), http://files.archivists.org/pubs/DACS2E-2013.pdf.

30. Mary Lynn Ritzenthaler and Diane Vogt-O'Connor, Photographs: Archival Care and Management (Chicago: Society of American Archivists, 2006). 
Collection Boxes 125-126 and the DOP Collection. This is because archives have traditionally dealt with both photographs and manuscript materials.

The Society of American Archivists' Describing Archives: A Content Standard (DACS) is an official content standard in the United States for describing archival and manuscript materials. ${ }^{31} D A C S$ conforms to the basic archival principles and descriptive elements outlined in the accepted international standard General International Standard Archival Description $(\operatorname{ISAD}(G))$. Although DACS is often paired with encoding standards, such as MARC 21 Format for Bibliographic Data or Encoded Archival Description (EAD), it is applicable to various systems of archival description, including traditional paper-based finding aids. In relation to this applied project, $D A C S$ was consulted in determining the fields of description in the final item-level finding aid for the Library's Mss Collection Boxes 125-126. Moreover, $D A C S$ encourages professional judgment in developing the local, institutional-specific standards "based on the requirements of a particular description, on the use of the material being described, or on the descriptive system being used." 32 This principle allowed room to incorporate local examples, such as Dudley's finding aid, into the creation of the item-level finding aid for the Muray materials.

While $D A C S$ serves as a technical guide to compiling finding aids and other forms of archival description, Kathleen D. Roe's Arranging \& Describing Archives \& Manuscripts focuses on theories and principles of archiving. ${ }^{33}$ It describes in simple terms the nature and purpose of archival arrangement and description. In the section "The Relationship of Archival Descriptive Practice to Libraries and Museums," Roe refers to the challenges an institution may face in undertaking the mission of providing access to mixed collections of archival, library, and museum materials. ${ }^{34}$ The author emphasizes how different

31. Society of American Archivists, Describing Archives: A Content Standard, 2nd ed. (Chicago: Society of American Archivists, 2013), http://files.archivists.org/pubs/DACS2E-2013.pdf.

32. Ibid, 4.

33. Kathleen D. Roe, Arranging \& Describing Archives \& Manuscripts (Chicago: Society of American Archivists, 2005).

34. Ibid, 17. 
types of collection materials - whether distinctive in physical characteristics and/or purpose of creation-affect the methodologies of collection arrangement and description. She writes:

Simply using one set of descriptive principles on all three types will ultimately limit accessibility to and comprehensibility of the resources. Some efforts have been made to provide 'seamless' access to combined materials, but a standardized, accepted approach to integrating catalog or Web sites for materials with different control issues have not been achieved or even widely discussed across professions. ${ }^{35}$

Nearly a decade after Roe's indication, areas of development and implementation of standardized, integrated cataloguing systems for archival, library, and museum collections remain under-researched and under-developed. Although there are systems that attempt to do this using the Dublin Core metadata scheme, they fail because it is a one-size-fits-all schema that is far from perfect.

Helena Zinkham's “Description and Cataloging,” in Mary Lynn Ritzenthaler and Diane Vogt-O’Connor's Photographs: Archival Care and Management, addresses the fundamental differences between archival description and museum cataloguing. ${ }^{36}$ Archives advocate multi-level descriptions that highlight the hierarchical relationship between the whole collection and its parts because that is how the collections exist, and the way collections are described also provides contextual information about them. ${ }^{37}$ On the other hand, museums promote item-level descriptions that are based on "object types, physical media, and curatorial documentation" of collection objects. ${ }^{38}$ Arguably, such a description does a disservice to a photographic collection like Muray's where linkage to variants as well as negatives plays an important role. Zinkham's chapter, in a way, bridges the differences between archival description and museum cataloguing by applying the basic archival descriptive elements of $D A C S$ and $\operatorname{ISAD}(G)$ to the description of photographic collections. Nevertheless, her method is compatible with the creation of links between the Library's manuscript materials and the DOP Collection only within the same system of collection management (i.e., through finding aids or other forms of archival description).

35. Ibid.

36. Helena Zinkham, "Description and Cataloging," in Mary Lynn Rizenthaler and Diane Vogt-O'Connor, Photographs: Archival Care and Management (Chicago: Society of American Archivists, 2006).

37. Ibid, 167.

38. Ibid. 


\subsubsection{Museum Registration and Collections Management}

The American Association of Museums' MRM5: Museum Registration Methods explains in simple terms the essentials of museum registration and collections management. ${ }^{39}$ Specifically, Suzanne Quigley and Perian Sully's chapter "Computerized Systems" addresses the benefits of employing a collections management system to increase the efficiency of museum operations related to collections management. ${ }^{40}$ According to the authors, unlike traditional manual cataloguing systems, collections management systems, such as TMS, create a relationship between individual records and expand access points for retrieving information from the database. ${ }^{41}$ For my applied project, I chose to extend this approach by linking information about Muray's celebrity portraits between the Library's paper-based finding aid and the DOP TMS catalogue records.

At George Eastman House, the institution and department-specific manual titled "Department of Photography Cataloging Manual" ensures the consistency of data entry within TMS. ${ }^{42}$ For this applied project, the sections such as "Title / Title Assistant," "Date / Date Assistant," "Description," "Medium," "Dimensions," "Inscription(s)," "Related Works" and "Notes" were consulted in updating the DOP TMS catalogue records for Muray's photographic prints and negatives. Moreover, Tasha Lutek's applied thesis "The Specimens Box: A Case Study in Cataloguing at George Eastman House" was examined to identify texts that put the theory of museum cataloguing into practice. ${ }^{43}$

My survey of existing literature on expanding access to library manuscript and museum collections confirmed that the Richard and Ronay Menschel Library and the Department of Photography

39. Rebecca A. Buck and Jean Allman Gilmore, eds., MRM5: Museum Registration Methods, 5 th ed. (Washington, D.C.: AAM Press, American Association of Museums, 2010).

40. Suzanne Quigley and Perian Sully, "Computerized Systems," in Buck, Rebecca A. and Jean Allman Gilmore, eds. MRM5: Museum Registration Methods, 5th ed. (Washington, D.C.: AAM Press, American Association of Museums, 2010).

41. Ibid, 173.

42. George Eastman House, "Department of Photography Cataloging Manual," (working manual, Department of Photography George Eastman House, Rochester, New York, updated September 11, 2013).

43. Tasha Lutek, "The Specimens Box: A Case Study in Cataloguing at George Eastman House," master's thesis, Ryerson University and George Eastman House International Museum of Photography and Film, 2010, http://digitalcommons.ryerson.ca/cgi/viewcontent.cgi?article=2227\&context=dissertations. 
at George Eastman House historically have maintained distinct and unrelated cataloguing systems.

Theories and practices of collection management and development introduced in this survey—both for the manuscript and museum collections - affected the basis and rationale for the methodologies adapted to this applied project. 


\section{Methodology}

Both the Richard and Ronay Menschel Library Manuscript Collection (Mss Collection) and the Department of Photography Collection at George Eastman House hold a large number of Nickolas Muray's celebrity portraits. In the Library's Manuscript Collection, published examples of his celebrity works from magazines and newspapers are compiled in the format of scrapbooks as well as loose clippings and tear sheets. Most of these clippings were collected by press services such as Durrant's Press Cuttings. The Photography Collection consists of Muray's photographic prints and negatives of the corresponding images from the same period. However, information pertaining to his celebrity materials in the two collections has previously been unrelated in their respective cataloguing systems. Hence, the methodology behind this applied project was to establish the best approach to link the two systems, thereby increasing access to and enriching the information of both collections. Linkage of the two systems was achieved through the creation of item-level descriptions for individual celebrity portraits by Muray that were part of the Mss Collection Boxes 125-126 Nickolas Muray Illustrations (hereafter referred to as Mss Collection Boxes 125-126) in the Library's existing finding aid for the Nickolas Muray Manuscript Collection. In addition, the project also involved updating catalogue records within the museum's collections management system, The Museum System (TMS), for Muray's photographic prints and negatives of the matching images and their variants from the same photographic sessions. This chapter describes in detail the methodology and provides a rationale for the decisions made in processing the manuscript and photographic collections, respectively.

\subsection{Manuscript Collection}

\subsubsection{Preliminary Review}

The preliminary review of the existing finding aid for the Nickolas Muray Manuscript Collection was essential in determining the methodology of this applied project. This is because archival description places an emphasis on the multi-level hierarchical relationships between the whole collection (i.e., 
Nickolas Muray Manuscript Collection) and its parts (i.e., Mss Collection Boxes 125-126). ${ }^{44}$ In addition to a short biography of Nickolas Muray and information related to the provenance of the collection, the existing finding aid held at the Richard and Ronay Menschel Library included box-level descriptions with a list of sub-groupings (see Figure 1). After reviewing the documents, I wanted to establish a system that could 1) correspond to the tradition of museum cataloguing that focuses on item-level information of collection objects and 2) effectively create image-to-image links between the manuscript and photographic collections. ${ }^{45}$ To do this, I chose to expand the existing finding aid and create item-level (image-level) descriptions of the Mss Collection Boxes 125-126. This methodology also conforms to the archival concept outlined in $D A C S$ - that is, "Within a given body of material, the repository may choose to describe some parts at a greater level of details than others. $" 46$

\section{Nickolas Muray Manuscript Collection}

\section{Boxes 125-126}

I. Illustrations

\section{Box 127}

II. Printed articles on Muray and his work

III. Miscellaneous Printed Materials

IV. Muray Studio Advertising

V. Letter(s)

VI. Typescripts

\section{Box 128}

VII. Audio Tapes

Figure 1. Whole-part hierarchy of the Nickolas Muray Manuscript Collection

44. Helena Zinkham, "Description and Cataloging," in Mary Lynn Rizenthaler and Diane Vogt-O'Connor, Photographs: Archival Care and Management (Chicago: Society of American Archivists, 2006), 167.

45. Ibid. Zinkham addresses the fundamental difference between archival description and museum cataloguing (See also section 2.2.2.).

46. Society of American Archivists, Describing Archives: A Content Standard, 2nd ed. (Chicago: Society of American Archivists, 2013), xvii, http://files.archivists.org/pubs/DACS2E-2013.pdf. 


\subsubsection{Inventory and Data Collection}

Due to the large volume of the materials found in the Mss Collection Boxes 125-126, one of the major challenges from the inception of this applied thesis was to determine the appropriate scope of the project. Hence, in order to acquire a detailed understanding of the scope, content, and extent of the Mss Collection Boxes 125-126, the most obvious place to begin was to record a full inventory of the body of work —namely, two scrapbooks (one intact and one disassembled), clippings, tear sheets, and miscellaneous items including four magazines. This inventory process was completed using Microsoft Excel to create a spreadsheet. Since the disassembled scrapbook pages, clippings, tear sheets, and miscellaneous materials were arranged in no apparent order, temporary page and item numbers were assigned in the order they were found in the respective boxes. Fields noted in the spreadsheet for the two scrapbooks were based on Kristin E. Dudley's finding aid for the Models' Guild of Philadelphia Papers Collection available at the Richard and Ronay Menschel Library. They included scrapbook page number, image location within the page, subject, published title of the image (if different from the subject name), page title, date, original publication (including title, volume and issue number, date of publication, and page number), and scope and content (see Appendix A, Table 1). Although the majority of these fields do not conform to the standard archival fields outlined in $D A C S$, they were chosen in order to maximize access to the non-text-based information associated with Muray's manuscript materials. For clippings and tear sheets, an item number was recorded in place of the page number (see Appendix A, Table 2). Inventory of the miscellaneous periodicals was carried out in a similar manner as to the clippings and tear sheets; however, notes on the location of Muray's reproductions within the magazines were added (see Appendix A, Table 3). For all materials, the Scope and Content field, which is a descriptive field in DACS, was provided when captions from the original publication added significant information to the context of Muray's celebrity portraits. ${ }^{47}$ Muray's commercial advertising works were also noted in this field.

47. Ibid, 45. DACS defines the Scope and Content field as an element that "provides information about the nature of the materials and activities reflected in the unit being described to enable users to judge its potential relevance." 
The inventory process revealed that the Mss Collection Boxes 125-126 roughly traced the chronology of Muray's career as a magazine and newspaper photographer. While the majority of the photomechanical reproductions found in the intact scrapbook, clippings and tear sheets consisted of Muray's celebrity materials, a great number of his advertising photographs for women's fashion were recorded in the disassembled scrapbook. ${ }^{48}$ At this point, a decision was made to limit the scope of this applied project to Muray's celebrity portraits published between 1920 and 1932, excluding his commercial advertising works (see Figures 2-3).
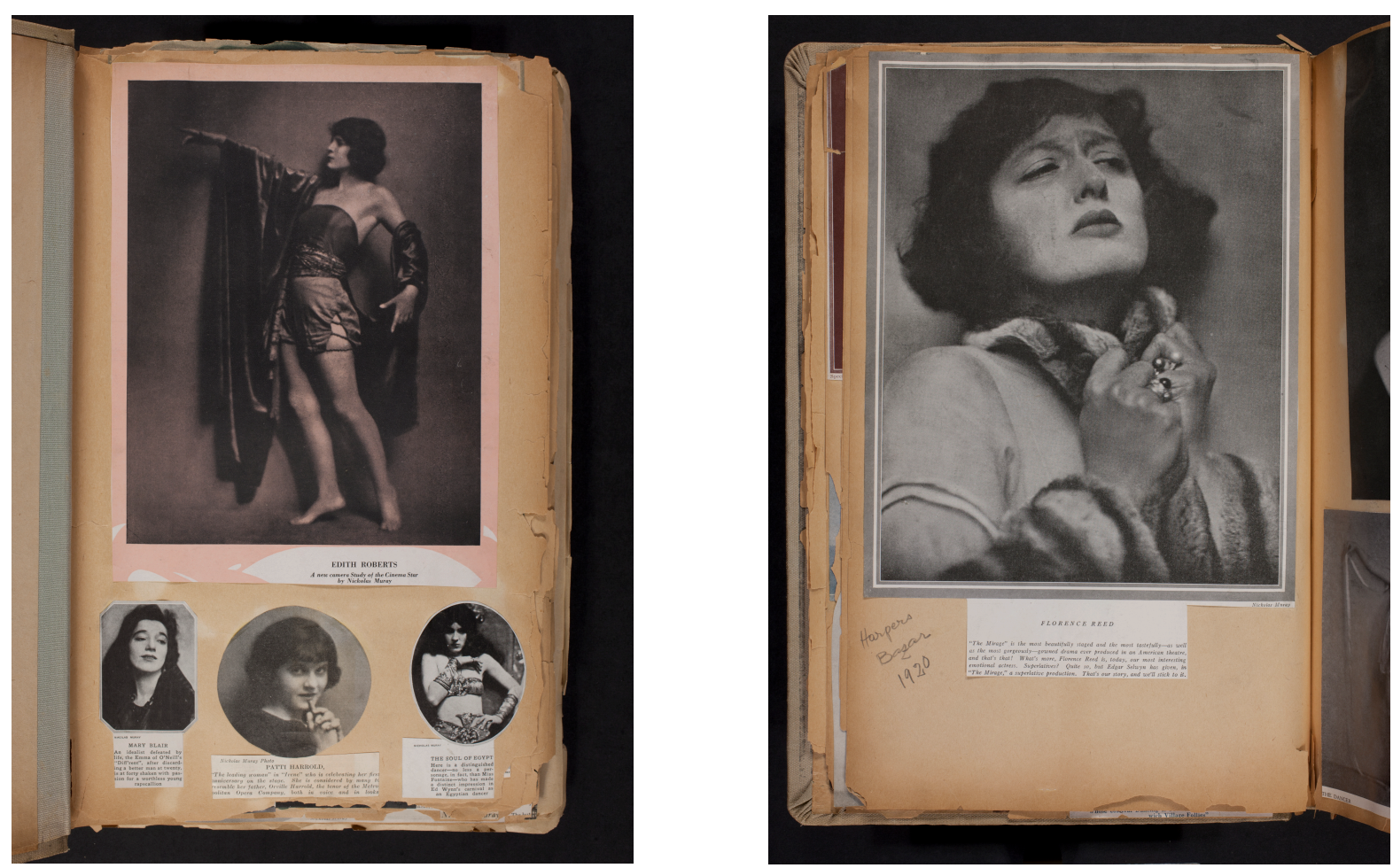

Figure 2. Samples of Muray's celebrity portraits Nickolas Muray Mss Collection Box 125, Folder 1: Scrapbook 1, (Left) page 1 and (Right) page 18

48. Suna and Inan Kiraç Foundation, Pera Museum, Nickolas Muray: bir fotoğrafçinin portresi=Portrait of a Photographer (Istanbul: Pera Museum Publication, 2013), 21. Following the U.S. stock market crash on October 29, 1929, and the ensuing Great Depression, Nickolas Muray shifted his photographic career from celebrity portraiture to commercial advertisements in 1931. 

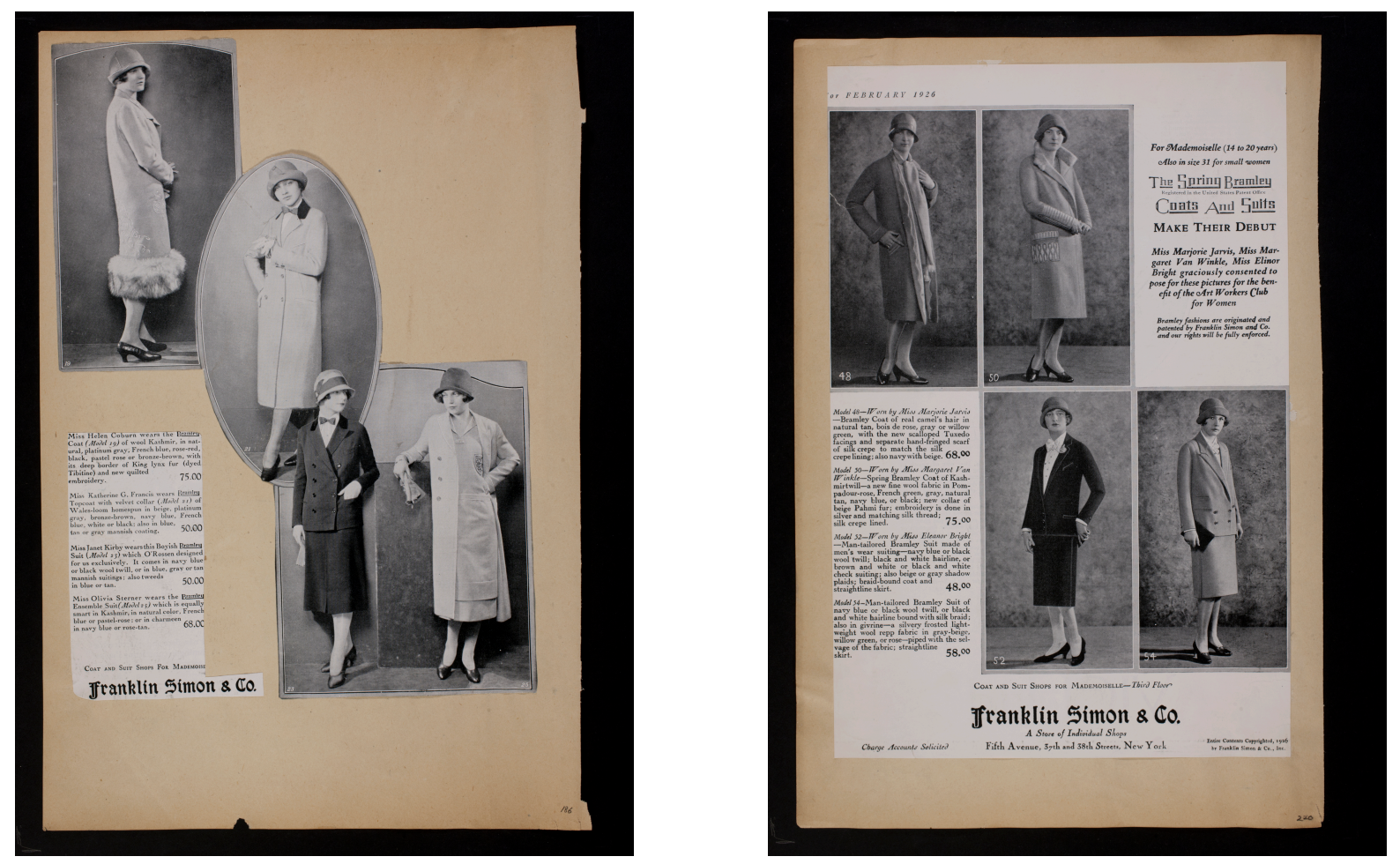

Figure 3. Samples of Muray's commercial advertising works

Nickolas Muray Mss Collection Box 126, Folder 14: Scrapbook 2, (Left) page 186 and (Right) page 220

While the majority of the tear sheets retained information regarding their source, many of the clippings required additional research into their original publication. Thus, once the inventory of the manuscript materials was complete, the next step involved locating the source of publication for Muray's celebrity portraits that were not accompanied by any information regarding their source of publication. In order to further narrow the scope of this applied project, I chose to survey the following publications: the complete issues of Theatre Magazine, Vanity Fair, and Vogue published between 1920 and 1932, as well as available issues of Harper's Bazar, Motion Picture Magazine, Motion Picture Classic, and Shadowland from the same period (see Figures 4-5). ${ }^{49}$ These magazines were chosen because of their

49. Facsimiles of Theatre Magazine and Vanity Fair were consulted at the Toronto Reference Library. Entire issues of Vogue have been digitized; thus, the magazine was accessed through ProQuest available from the Ryerson University Library \& Archives website. Harper's Bazar was surveyed at the New York Public Library both through hardcopies and microfilms. The Richard and Ronay Menschel Library at George Eastman House holds selective issues of Motion Picture Magazine and Motion Picture Classic, as well as the journals The Camera and American Photography. Selected issues of Motion Picture Magazine and Motion Picture Classic as well as Shadowland magazine were also available on the Media History Digital Library website (http://mediahistoryproject.org/collections/). For detailed issues of consultation, see Bibliography. 

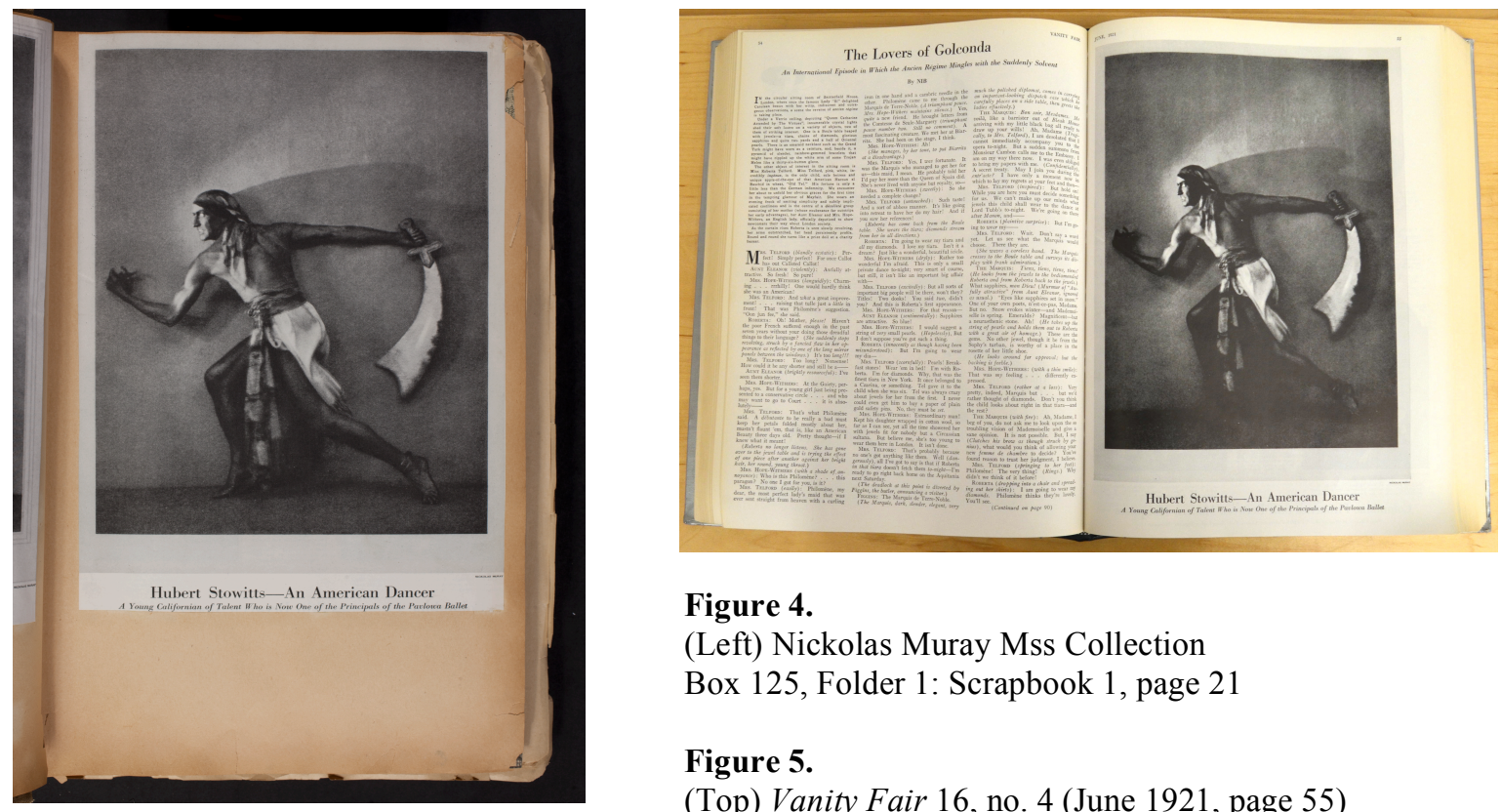

\section{Figure 4.}

(Left) Nickolas Muray Mss Collection

Box 125, Folder 1: Scrapbook 1, page 21

\section{Figure 5.}

(Top) Vanity Fair 16, no. 4 (June 1921, page 55)

genre and focus on stage and theatre stars. Although Vogue and Harper's Bazar placed less emphasis on theatrical entertainment and focused more on fashion advertisements, Muray's celebrity portraits were often reproduced in features such as Vogue's "Seen on the Stage." Some findings were also made in journals such as The Camera and American Photography. Of 760 celebrity portraits found in the Mss Collection Boxes 125-126, I was able to locate the original publication for 524 of them; the information, to the extent available, was then added to the spreadsheet created during the inventory process.

The next step in gathering the necessary data for the spreadsheet involved identifying the matching celebrity portraits and their variants in the museum's Photography Collection, using the search options in TMS. As a result, the field "Related Materials" was added to the spreadsheet, noting the accession numbers for the matching photographic prints and negatives and their variants from the same photographic sessions (see Appendix A, Table 4). However, it is important to note that in practice, additional matches were also found later during the object cataloguing process (which is discussed in section 3.2.1), as I physically examined Muray's celebrity portraits-in particular, his nude portraits and photographs of dancers. 


\subsubsection{Arrangement and Organization}

The preceding inventory process helped to establish an understanding of how the materials in the Mss Collection Boxes 125-126 were hitherto organized. This understanding facilitated determining their final arrangement for the creation of item-level descriptions. In the broad sense, the materials were organized by format—while Box 125 consisted of 1) the intact scrapbook and 2) clippings, tear sheets and miscellaneous magazines, Box 126 contained solely the disassembled scrapbook pages. However, within this broad scheme of organization, some clippings and tear sheets were placed into folders, labeled "I: 3, Misc." and "CLIPPINGS," while others were housed separately in plastic sleeves and stored together with the miscellaneous magazines. Likewise, the disassembled scrapbook pages from Box 126 were in no apparent order. Nevertheless, since the majority of Muray's commercial advertising works were located at the top of a pile of the scrapbook pages and many of his celebrity materials were found in the bottom of the box, it seemed most likely that the pages were turned upside down from their actual chronology at some point in the past. ${ }^{50}$

In determining the final arrangement of Muray's manuscript materials, I chose to acknowledge the fundamental archival principle of respect des fonds outlined in DACS by preserving the original order of the intact scrapbook. The pages of the intact scrapbook were too fragile to number, so an alternative method was used-it will be discussed in section 3.1.4. On the other hand, since the clippings, tear sheets, miscellaneous items and disassembled scrapbook retained no discernible order, I decided to impose a new organizational system onto them. This decision was supported both in DACS and by Brett Carnell in his essay "Accessioning and Arrangement." Carnell writes, "Often, there is no evidence that any order ever existed. The archivist should develop an arrangement (based on creator, format, function, genre, subject, or chronology) that will benefit the anticipated users of the collection." 52 Accordingly, in order to

50. See footnote 39 .

51. Brett Carnell, "Accessioning and Arrangement," in Mary Lynn Rizenthaler and Diane Vogt-O'Connor, Photographs: Archival Care and Management (Chicago: Society of American Archivists, 2006).

52. Ibid, 151. 
increase the accessibility of the clippings and tear sheets, I chose to organize them first by subject (i.e. celebrity portraits and commercial advertising photography) and then by publication titles. This organization was further reinforced by creating archival file folders to improve the physical control of the materials (see Figures 6-7). Major magazine publications for which Muray worked were assigned individual folders and arranged chronologically inside their respective folders, while miscellaneous and unknown publications were arranged alphabetically by publication titles, when available, and then chronologically. Newspaper clippings and tear sheets were also given a separate folder. The following step included allocating item numbers to the clippings and tear sheets by enclosing an acid-free archival paper with the necessary information, e.g. "Box 125, Folder 2: Clippings and Tear Sheets (Celebrity Portraits, Theatre Magazine), item 1," into the respective plastic sleeves (see Figure 8). Both the folder and item numbers assigned at this point were reflected in the final finding aid, thus, ensuring both physical and intellectual control of the materials. Similarly, magazines and a cardboard-mounted clipping (miscellaneous materials) were grouped together `into a separate folder, where they were arranged alphabetically by title and then chronologically ordered.

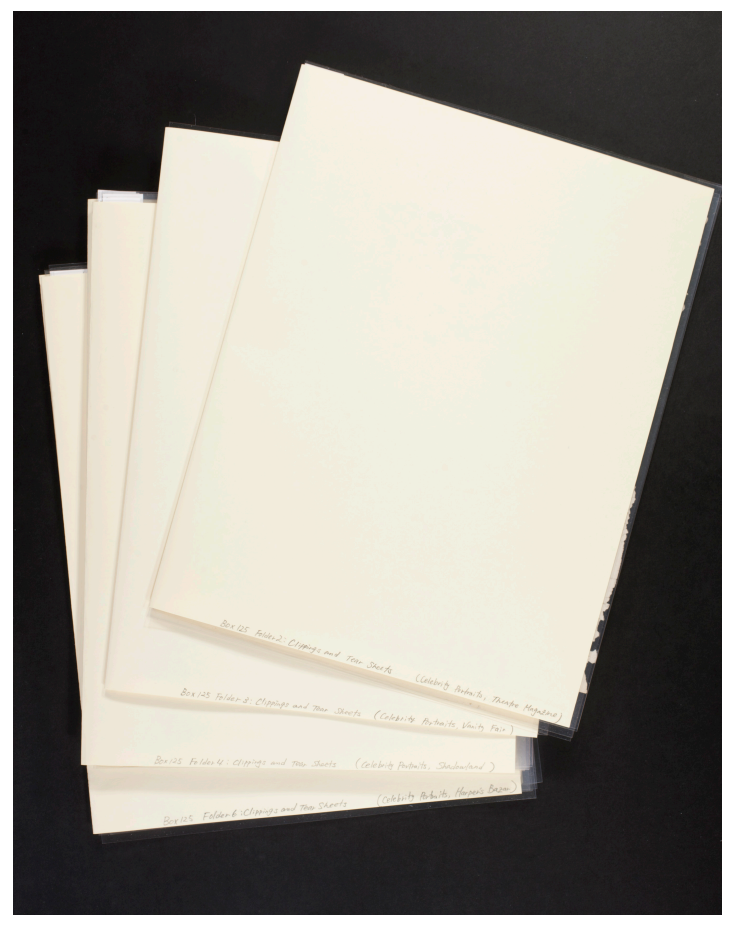

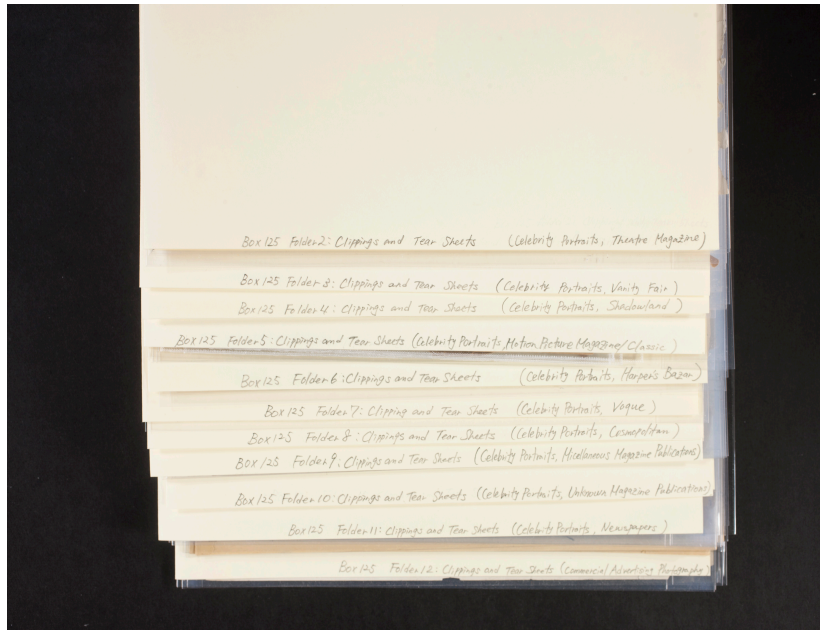

Figure 6.

(Left) Sample of folders for clippings and tear sheets

Figure 7.

(Top) Detail of folders for clippings and tear sheets 

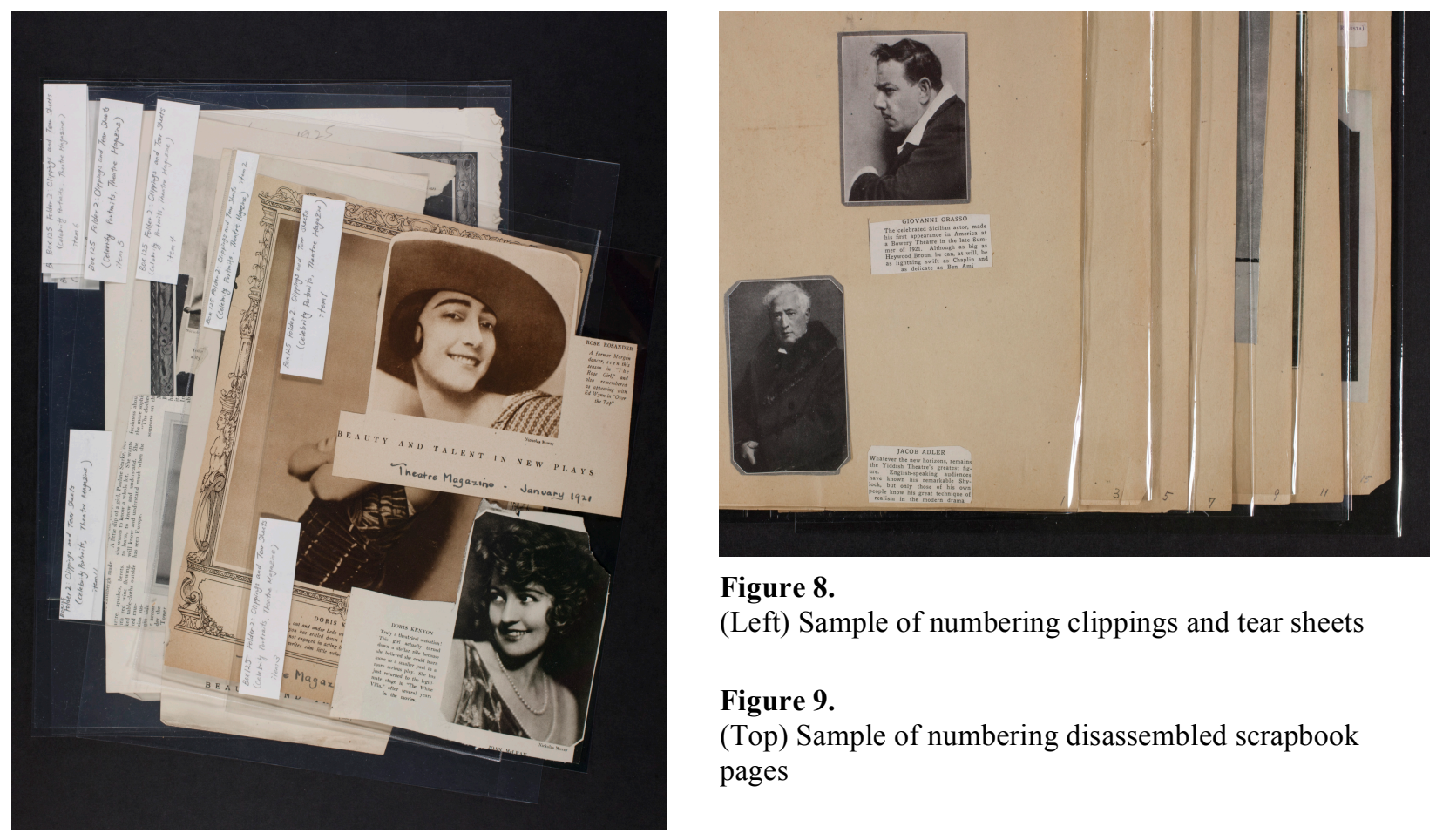

Figure 8.

(Left) Sample of numbering clippings and tear sheets

Figure 9.

(Top) Sample of numbering disassembled scrapbook pages

Among the most challenging tasks of this applied project was to develop an arrangement that not only increased the accessibility of the disassembled scrapbook, but also made sense of its available information. This was, to a large extent, because each page included clippings of different subjects, sitters, dates and publication sources; thus, I was unable to arrange the material by any of the abovementioned classifications. Moreover, since the sources for many of the commercial advertising works were not identified, dates related to those images and publications remained unknown. Therefore, applying chronology as a form of order for the disassembled scrapbook was impossible. As a result, the pages were arranged based on a reverse of the original order found in the box, as the earliest items were found to be at the bottom of the box. In addition, some modifications to order were made when deemed necessary. Once the new order of the disassembled scrapbook was determined and physically imposed, I requested permission to number the pages with pencil in the bottom right corners. Permission was granted by Lisa Hostetler, Curator-in-Charge, and I proceeded with numbering the pages (see Figure 9). In respecting the format that the scrapbook would have had in its original bound form, the numbers were assigned on both the recto and verso of the pages. 


\section{Box 125}

Folder 1: Scrapbook 1

Folders 2-12: Clippings and Tear Sheets

Celebrity Portraits

Folder 2: Clippings and Tear Sheets (Theatre Magazine)

Folder 3: Clippings and Tear Sheets (Vanity Fair)

Folder 4: Clippings and Tear Sheets (Shadowland)

Folder 5: Clippings and Tear Sheets (Motion Picture Magazine / Motion Picture Classic)

Folder 6: Clippings and Tear Sheets (Harper's Bazar)

Folder 7: Clippings and Tear Sheets (Vogue)

Folder 8: Clippings and Tear Sheets (Cosmopolitan)

Folder 9: Clippings and Tear Sheets (Miscellaneous Magazine Publications)

Folder 10: Clippings and Tear Sheets (Unknown Magazine Publications)

Folder 11: Clippings and Tear Sheets (Newspapers)

Commercial Advertising Photography

Folder 12: Clippings and Tear Sheets (Commercial Advertising Photography)

\section{Box 126}

Folder 13: Miscellaneous Materials

Folder 14: Scrapbook 2 (Disassembled)

Figure 10. Overall organization of the Mss Collection Boxes 125-126 Nickolas Muray Illustrations

Figure 10 demonstrates the implemented overall organization of the Mss Collection Boxes

125-126. After the physical rearrangement and numbering of the manuscript materials were complete,

these changes were also added to the spreadsheet so that they could be applied to the final item-level

finding aid discussed in the following section. At this point, notes on the links between related

reproductions of Muray's celebrity portraits and variants within the Manuscript Collection were added to

the "Related Materials" field of the spreadsheet (see Appendix A, Table 5 and Figures 11-12).

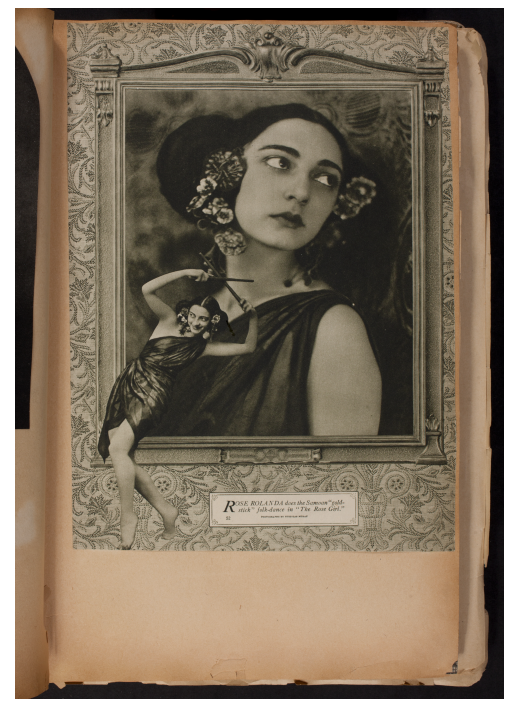

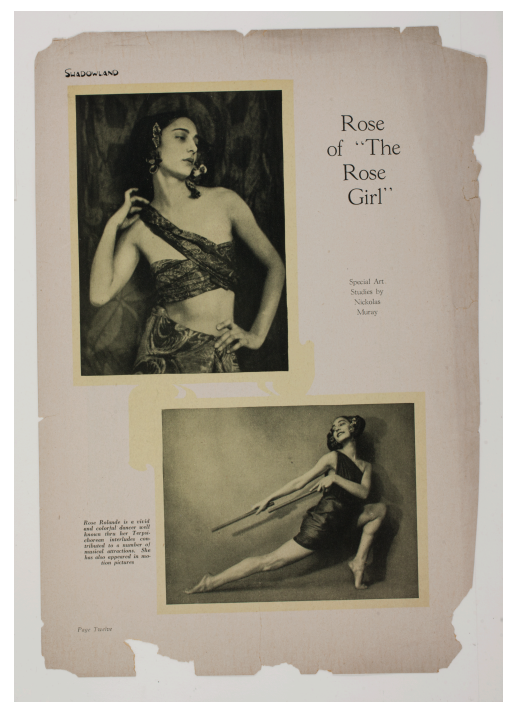

Figure 11.

(Left) Nickolas Muray Mss Collection Box 125, Folder 1: Scrapbook 1, page 23

Figure 12.

(Right) Nickolas Muray Mss Collection Box 125, Folder 4: Clippings and Tear Sheets, item 9 


\subsubsection{Creation of Item-Level Finding Aid}

The compilation of item-level descriptions for the Mss Collection Boxes 125-126 was achieved through the use of the "Mail Merge" function under the Mailings tab found in Microsoft Word. Thus, all necessary fields of description for the final item-level finding aid were imported directly from the Excel spreadsheet. This document was then incorporated into the existing collection-level and box-level descriptions for the Nickolas Muray Manuscript Collection. Additional explanations pertaining to the organization of Muray's Illustration materials were included in the legend, in order to ensure the accessibility of the materials to future researchers. (See Appendix B for examples of the final item-level descriptions.) Printed and digital (CD-ROM) copies of the final finding aid were provided to the Richard and Ronay Menschel Library so that researchers would be able to consult them in the future.

The final step in processing Muray's Manuscript Collection involved creating facsimile copies of the two scrapbooks in an effort not only to improve access to but also to aid in the preservation of the materials. Mary Lynn Ritzenthaler supports this notion of access and preservation when she writes, “access copies of photographs provide indirect preservation benefit by minimizing random browsing through files and the handling of originals." ${ }^{, 53}$ Limiting the physical handling of Muray’s manuscript materials - in particular, the intact scrapbook with brittle pages — was especially important since the pages were too fragile to be numbered with pencil. Thus, the pages of the access copy were numbered in place of the originals. Moreover, the creation of the access copy enhanced the physical control of the disassembled scrapbook, for unnecessary handling of the pages by future researchers could easily disorder the imposed arrangement. With the assistance of the George Eastman House photographer, Barbara Galasso, each page of the two scrapbooks was photographed. The pages were then cropped and assigned page numbers corresponding to the item-level descriptions. Both printed and digital (DVD-ROM)

53. Mary Lynn Ritzenthaler, "Copying and Duplication," in Mary Lynn Rizenthaler and Diane Vogt-O'Connor, Photographs: Archival Care and Management (Chicago: Society of American Archivists, 2006), 352. 
versions of the access copy (300 DPI) were provided to the Library to be placed with the finding aid for the Nickolas Muray Manuscript Collection.

\subsection{Photography Collection}

The second part of this applied project consisted of revising Department of Photography (DOP) TMS catalogue records for Nickolas Muray's photographic prints and negatives—specifically, the ones with corresponding images to those found in the Library's Manuscript Collection and their variants from the same photographic sessions (see Figures 13-15). This section outlines the methodology that was established in order to effectively incorporate the information attained from the Mss Collection Boxes 125-126 into the existing DOP TMS catalogue records, thus expanding information about and access to the photographic prints and negatives. Additionally, the methodology aims to direct future researchers of Muray's photography to the Library's Manuscript Collection, by informing them of the matching celebrity portraits and their variants in its collection. The process of updating these records happened in two phases - the first phase was concerned with object-based cataloguing as well as a survey of Muray's photographic prints and negatives, while the second phase focused on linking information between his celebrity portraits found in both the Manuscript and Photography Collections.
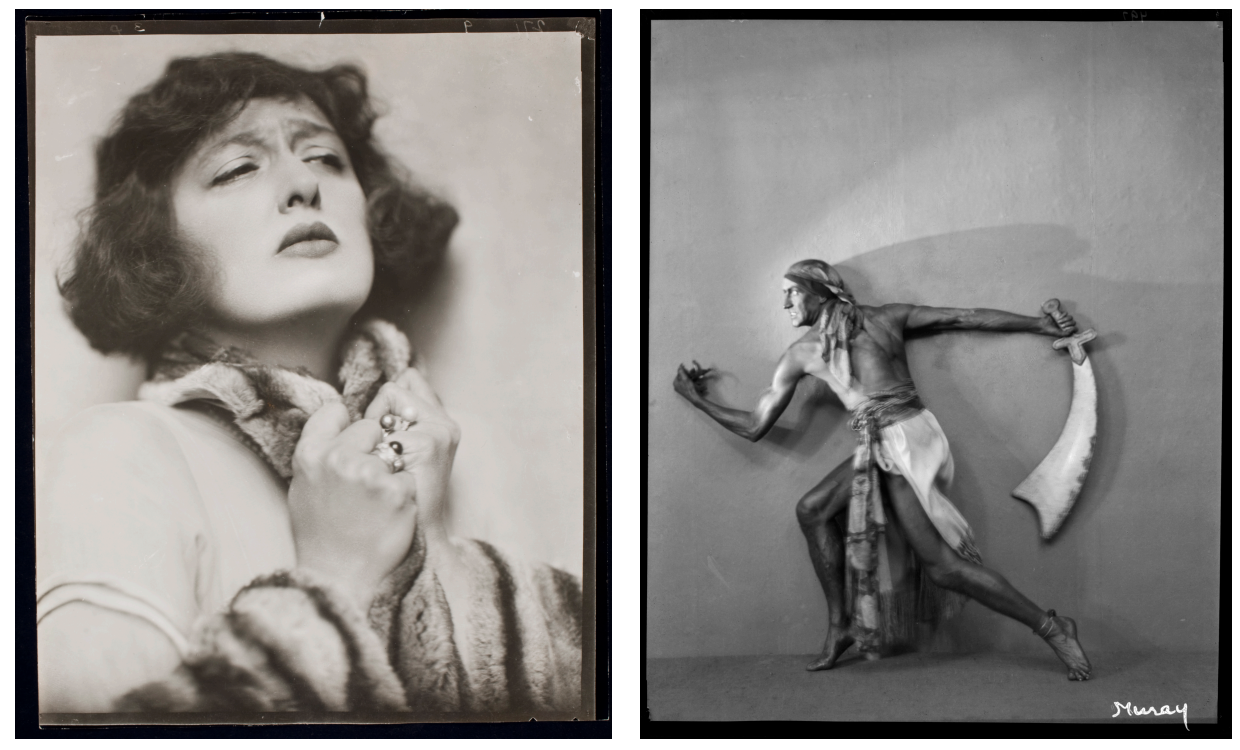

Figure 13 .

(Left) Nickolas Muray

Florence Reed, 1920

Gelatin silver print

1977:0188:2318

\section{Figure 14.}

(Right) Nickolas Muray

Hubert Stowitts-An

American Dancer, ca.1921

Negative, gelatin on

nitrocellulose sheet film

1977:0189:2787 


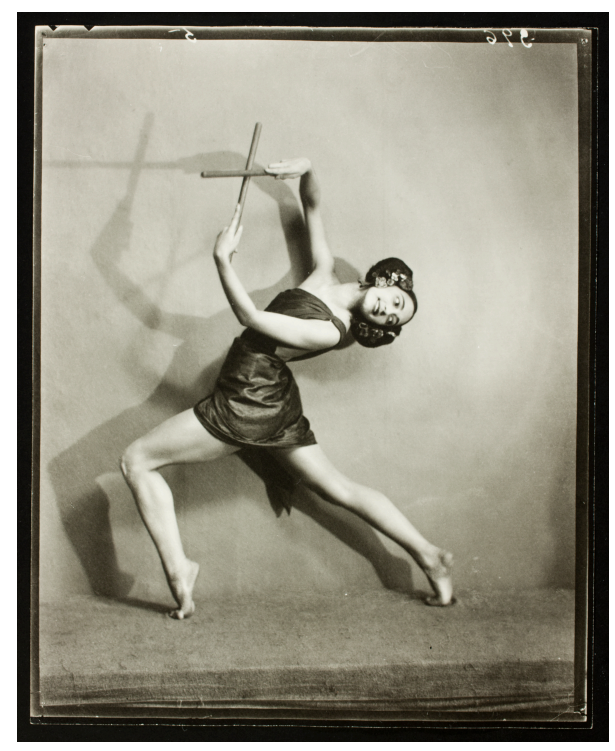

\section{Figure 15.}

Nickolas Muray

Rose Rolando, ca.1921

Gelatin silver print

1977:0188:2398

\subsubsection{Object-Based Cataloguing and Survey of the Photography Collection}

To overcome the large number of matching celebrity portraits and their variants found in Muray's photographic prints and negatives, a decision was made to give priority to 496 gelatin silver prints for object-based cataloguing. ${ }^{54}$ This decision was based on the anticipated use of the collection by future researchers. With the assistance of Joe Struble, Collection Manager, and Ross Knapper, Assistant Collection Manager, I catalogued the gelatin silver prints and made necessary changes to the following TMS fields: Dimension, Inscription, and when applicable, Title on Object and Date (see Appendix C for samples of object-based catalogue records). All necessary modifications were made based on the standards outlined in "Department of Photography Cataloging Manual," the department-specific manual for cataloguing in TMS at George Eastman House. ${ }^{55}$

Although the process of object-based cataloguing was not explicitly part of the linking of the information between the Manuscript and Photography Collections, I would like to emphasize the

54. The total of 747 photographic prints and negatives were identified to be matching with or variants of Muray's celebrity portraits that were reproduced between 1920 and 1932 and found in the Mss Collection Boxes 125-126. The following specifies the distribution of the prints and negatives: 496 gelatin silver prints, 243 cellulose nitrate negatives, 7 cellulose acetate negatives and 1 glass plate negative.

55. George Eastman House, "Department of Photography Cataloging Manual," (working manual, Department of Photography George Eastman House, Rochester, New York, updated September 11, 2013). 
significance of the process for two reasons. First, by physically examining the photographic prints, I was able to gain a better understanding of the scope and organization of Muray's celebrity materials in the Department of Photography Collection —while the majority of his celebrity portraits are arranged and stored alphabetically by sitter's last name, some are organized by categories (such as "nudes" and "dancers") and stored in boxes separately from the rest of the materials. ${ }^{56}$ Second, the process of object-based cataloguing permitted an assessment of the complete body of work for this project because identifying matches between the Manuscript and Photography Collections solely via TMS search options (discussed in section 3.1.2.) was impossible. This was especially the case when subjects of Muray's celebrity portraits in either collection were unidentified. For previously unidentified sitters, a search by name could not be performed in TMS; therefore, I was unable to identify matches using the "Object Related" function. Hence, a survey of Muray's “nudes” and “dancers” boxes, which contained his figure studies with unidentified subjects, was particularly helpful in locating additional matches between the two collections.

\subsubsection{Linking of Information}

For all photographic prints and negatives, the following Department of Photography TMS fields were revised: Constituent(s) (when applicable), Title, Date, Medium, Description, Notes, and Related Works. I will now discuss updates for the Published Title, Date, Description, Related Works, and Notes fields and how these fields were used to create intellectual links between Muray's celebrity portraits found in both the Manuscript and Photography Collections.

\section{Published Title}

Published titles from Muray's manuscript materials were added to the Title field in TMS for

56. Some of the celebrity materials are arranged by categories in order to accommodate different needs of anticipated researchers. While some researchers may be interested in Muray's portraits of particular sitters, others may request examples of his typical subjects such as nude portraits and photographs of dancers. 
the matching images in the Photography Collection. ${ }^{57}$ For example, the published title Hubert

Stowitts-An American Dancer was supplemented in the existing TMS catalogue records for

1977:0189:2787 (see Figure 16). Based on the guideline outlined in the department's cataloguing manual, the note "Published title from Vanity Fair 16, no. 4 (June 1921, page 55)" was also entered in the remarks box associate with the title. ${ }^{58}$

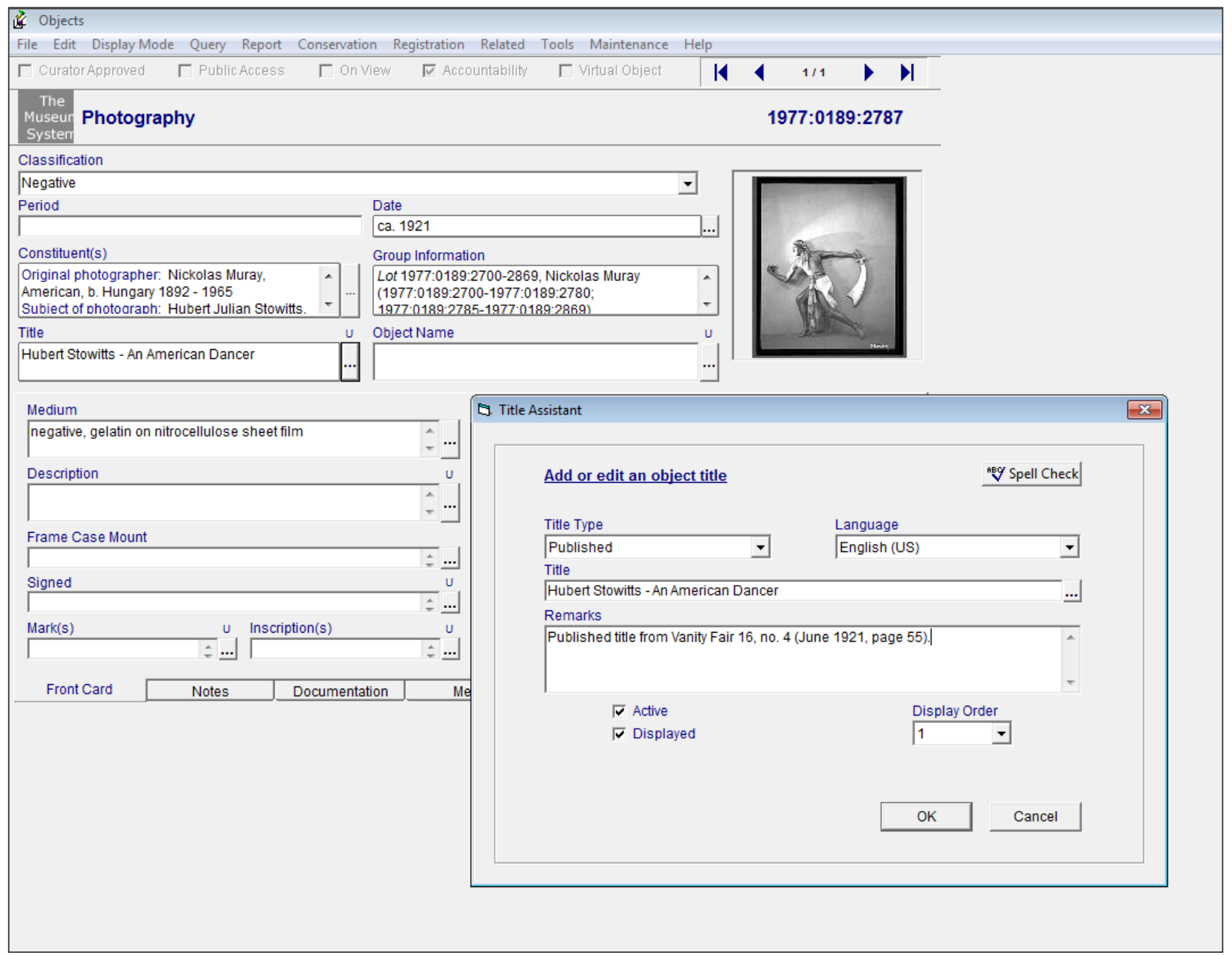

Figure 16. Sample of updated Title field in TMS, 1977:0189:2787

57. Note that published titles were only associated with the matching images but not the variants.

58. "A note should be added to the REMARKS box associated with the title noting pertinent information about the publication from which the PUBLISHED TITLE was taken (including but not limited to author, title, publisher, date and page number)." George Eastman House, "Department of Photography Cataloging Manual," (working manual, Department of Photography George Eastman House, Rochester, New York, updated September 11, 2013), 22. 
Date

Many of the existing TMS catalogue records for Muray's celebrity portraits included only approximate dates of production, for instance, ca. 1922-1961. The following questions were considered in order to narrow down the approximate dates of publication for the photographic prints and negatives:

- Is the source of original publication identified for the matching image(s) and/or variant(s) in the Mss Collection Boxes 125-126?

- Does the caption for the matching image(s) and/or variant(s) in the Mss Collection Boxes 125-126 reveal information pertaining to the dates of publication and/or the dates of production of the photographs?

- Is/Are there (a) matching image(s) and/or variant(s) with known publication source other than those found in the Mss Collection Boxes 125-126? If so, is/are the date(s) of publication earlier than that/those of the matching image(s) and variant(s) found in the Mss Collection Boxes 125-126? (See Appendix D for the flow chart demonstrating the step-by-step procedures I followed in order to determine the appropriate dates of production for the photographic prints and negatives.)

In general, when the source of publication was identified for the matching images and/or variants in the Mss Collection Boxes 125-126, "ca. [year of publication]" was added as the Date Label with the following Search Dates: Begin Date 1920 and End Date [year of publication]. ${ }^{59}$ Begin Date 1920 was based on the year Muray signed a contract with Condé Nast, the publisher of Vanity Fair and Vogue, and began actively producing celebrity portraits for magazines and newspapers. ${ }^{60}$ End Date [year of publication] was based on the premise that the creation dates for the photographic prints and negatives were no later than the publication dates for the magazine and newspaper reproductions (see Figure 17). When the year of publication was in 1920, the Date Label was entered as "1920" without "ca." (see

59. "SEARCH DATES provide a range of searchable dates for the object. [...] For circa dates, the BEGIN DATE and END DATE should encompass the possible range of dates for the image." Ibid, 19. City, in 1920.

60. Muray opened his first photography studio on 129 MacDougal Street in Greenwich Village, New York 
Figure 18). Moreover, if there was a matching image and/or a variant with a known publication date earlier than that found in the Mss Collection Boxes 125-126, the earliest known publication date was used regardless of whether the reproduction was present in the Library's Manuscript Collection.

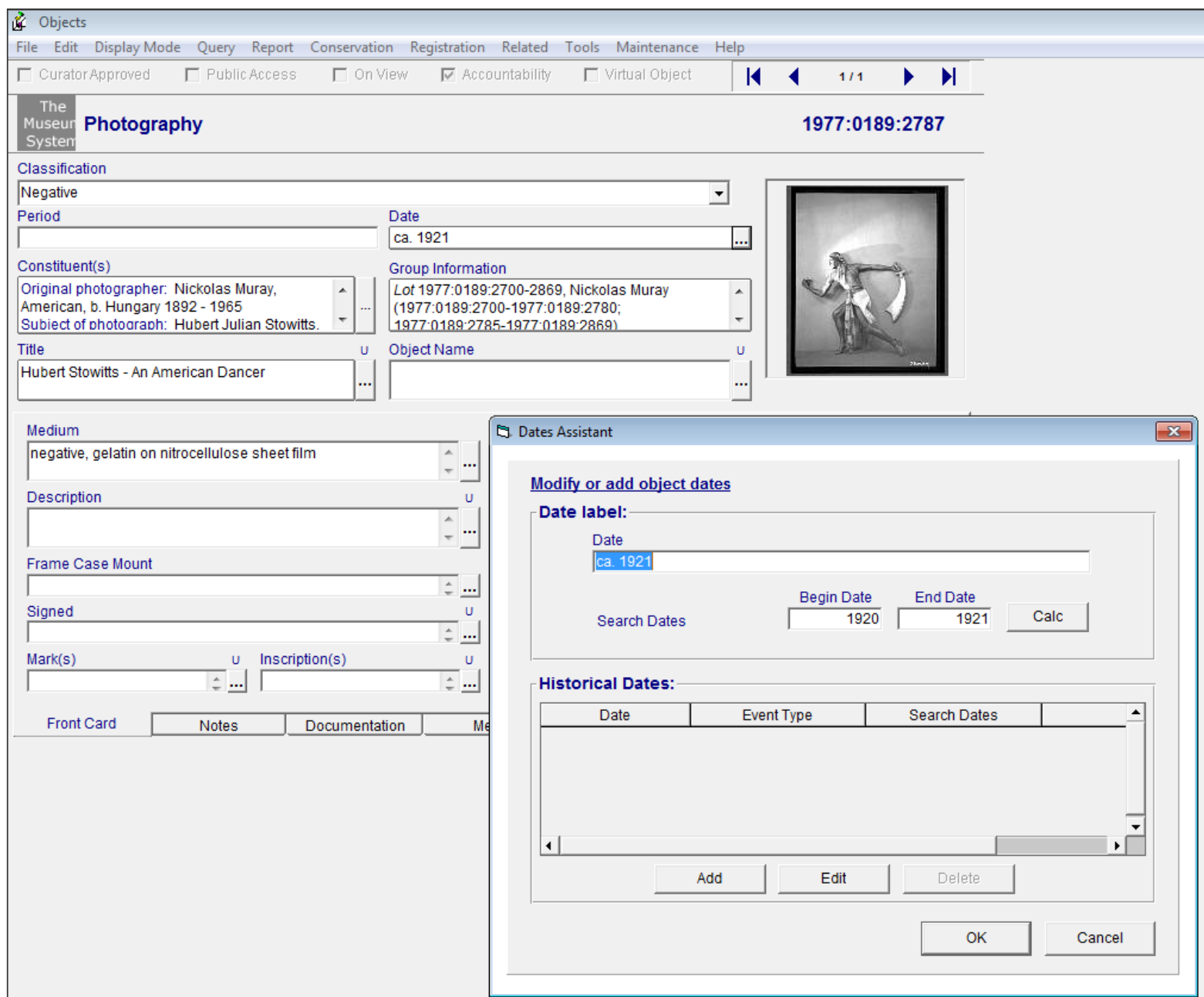

Figure 17. Sample of updated Date field in TMS, 1977:0189:2787 


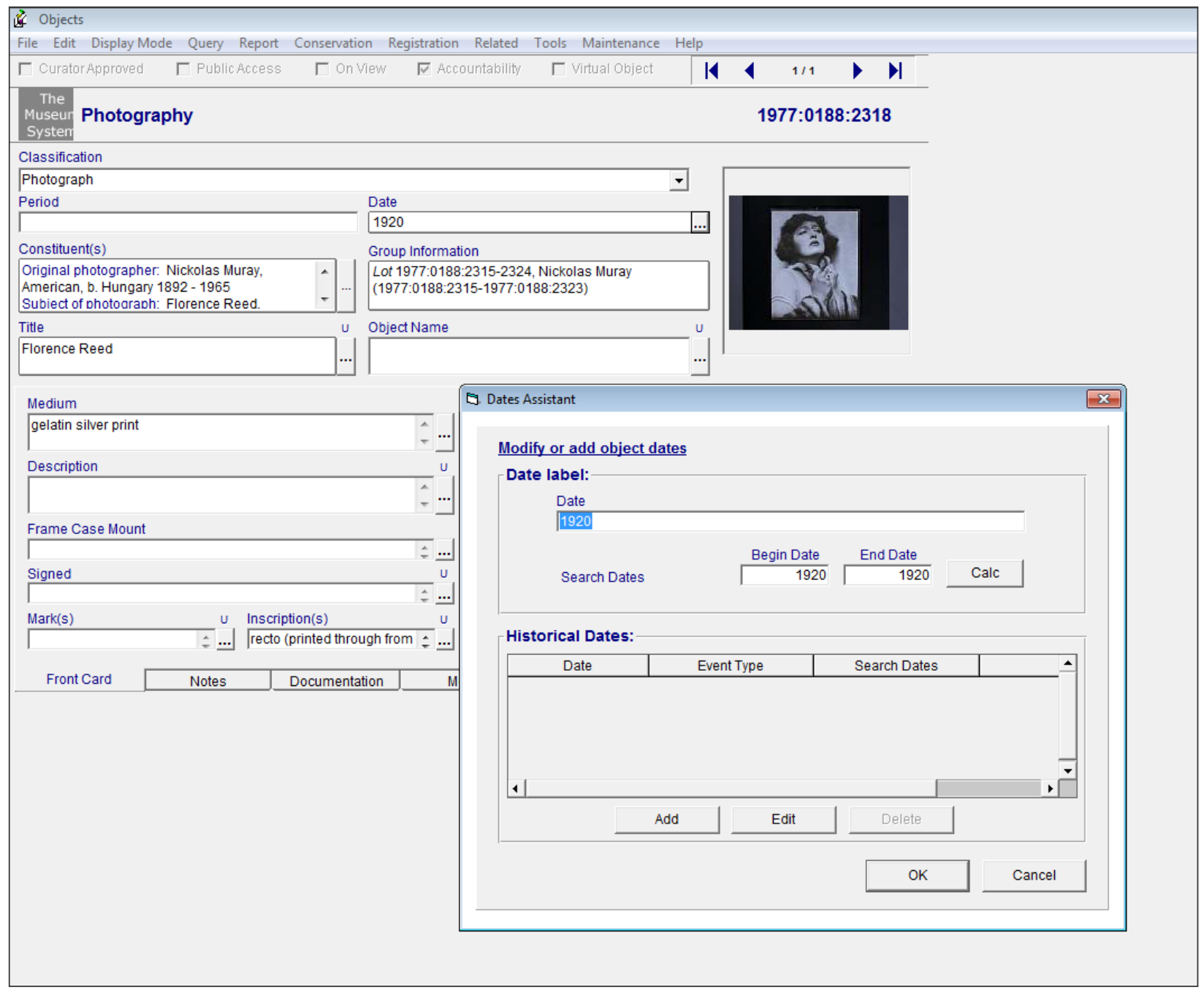

Figure 18. Sample of updated Date field in TMS, 1977:0188:2318

Many of Muray's theatrical photographs found in the Mss Collection Boxes 125-126 were accompanied by captions that offered a clue as to the date of publication and/or the date of production of the images. For example, the caption for Mss Collection Box 125, Folder 1: Scrapbook 1, page 23 (see Figure 11 in chapter 3.1.) referred to the Broadway play The Rose Girl, which premiered on February 11, 1921 and closed on May 7, $1921 .^{61}$ Although the date of publication for this particular reproduction was unidentified, the caption narrowed the approximate date of production for the dancing portrait of Rose

61. "The Rose Girl," IBDB: Internet Broadway Database, The Broadway League, accessed August 17, 2014, http://www.ibdb.com/production.php?id=9033. 
Rolando to ca. 1921 (Begin Date 1920 and End Date 1921).

Exceptions were made when Muray's celebrity portraits were published as part of retrospective features. Following the guideline in the museum's cataloguing manual, the circa dates for the Date Label were set midway between the Begin Date 1920 and the End Date [year of publication]. ${ }^{62}$ Finally, explanatory notes were added in the Notes field in order to describe my reasoning regarding the dates of production for the photographic prints and negatives (which is discussed later in this chapter).

\section{Description}

When information related to the context of the photographic prints and negatives was available from the Library's Manuscript Collection, it was added to the Description field in TMS. This information was based on the captions for the magazine and newspaper reproductions of the matching images and their variants. Thus, the Description field in TMS corresponded to the Scope and Content field in the final item-level finding aid for the Mss Collection Boxes 125-126. For example, the description "Rose Rolando dancing the Samoan folk dance of 'The Rose Girl' (1921)," that was used in the Scope and Content field within the Library finding aid, was also added to the Description field for 1977:0188:2398 (see Figure 19). If I was uncertain of the degree to which the captions were related to the content of photomechanical productions, I gave priority to expanding access to and disclosing related materials in the Library's Manuscript Collection through the Notes field (discussed later in this section), rather than making an unjustified hypothesis. In the event that future researchers are interested in the materials, they will be able to locate and consult the matching manuscript images and their variants and use their own judgments with regards to the context of the photographic prints and negatives.

62. George Eastman House, "Department of Photography Cataloging Manual," (working manual, Department of Photography George Eastman House, Rochester, New York, updated September 11, 2013$), 22$. 


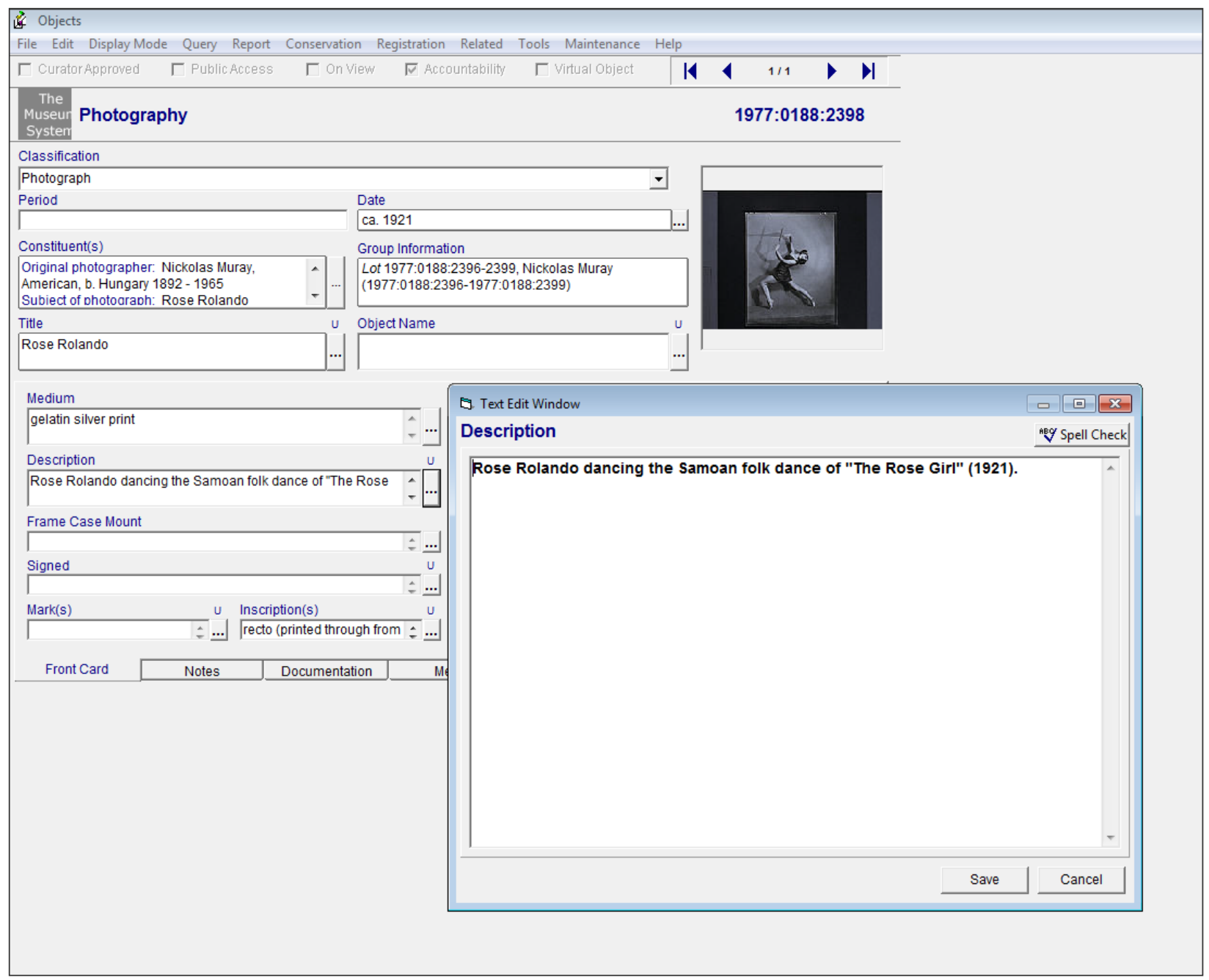

Figure 19. Sample of updated Description field in TMS, 1977:0188:2398

\section{Related Works}

Related photographic prints and negatives within the Muray celebrity portrait material in the Department of Photography Collection were linked through the Related Works field (see Figure 20). According to the museum's TMS cataloguing manual, "this field is used to make note of other GEH collection material that relates to the object being catalogued, such as variant or duplicate prints, and/or a corresponding negative or print." ${ }^{, 63}$ As demonstrated in Figure 20, two types of related works were added to this field: 1) "Negative/Print" and 2) "See Also" for the remaining photographic prints and negatives

63. Ibid, 46. 
with matching images and variants. Creation of these links was advantageous because traditional museum cataloguing merely places an emphasis on item-level information of individual collection objects. ${ }^{64}$
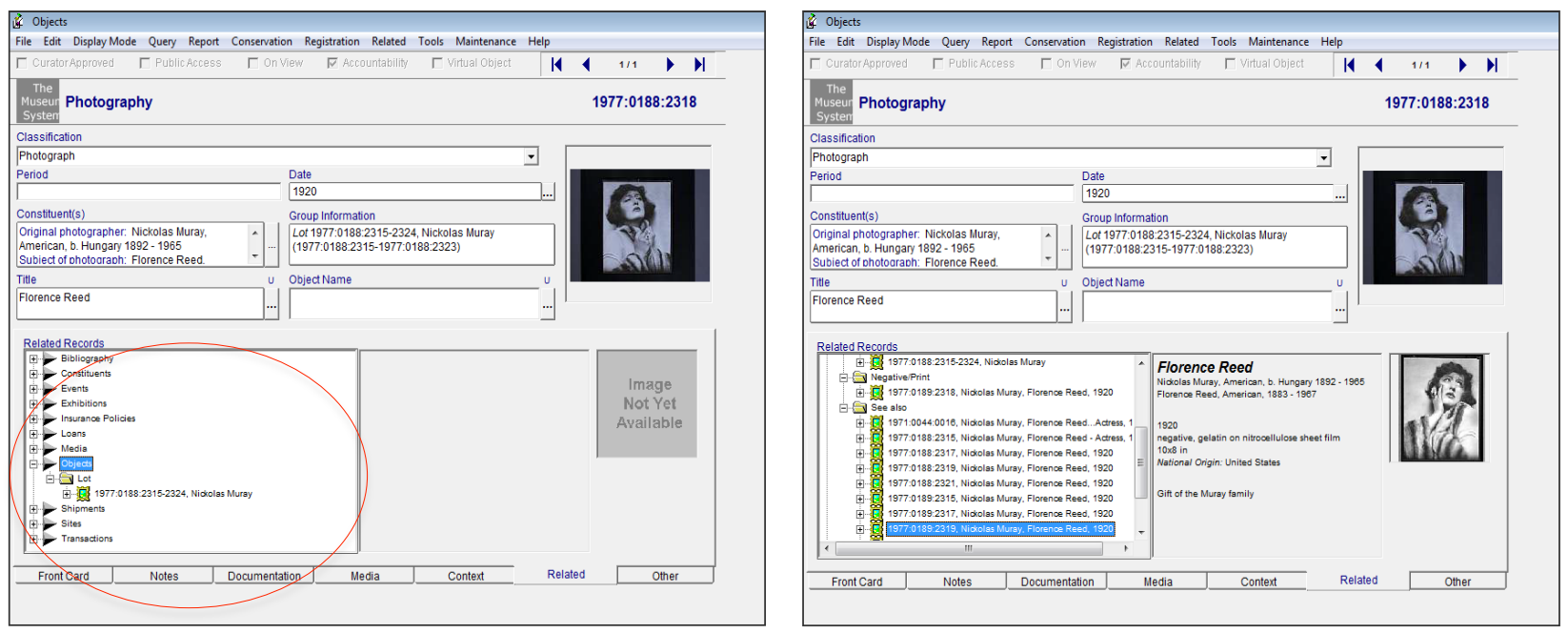

Figure 20. Before-and-after sample of the Related Works field in TMS, 1977:0188:2318

Notes

Hypothetically, it would have been ideal for the related manuscript materials to be added to the Related Works field in order to be linked with the Photography Collection. However, since the linkage of materials in the Related Works field requires an item-level record in TMS, and Library materials are currently not represented in this way, the best approach in creating links between the two collections was through the Notes field in Department of Photography TMS records. ${ }^{65}$ Thus, the locations of the matching manuscript images and variants were noted in this field. Additionally, this field was used for describing my reasoning for the updated dates of production for Muray's photographic prints and negatives. When applicable, notes on the source of information for the Published Title and Description fields were also included (see Figures 21-22).

64. Helena Zinkham, "Description and Cataloging," in Mary Lynn Rizenthaler and Diane Vogt-O’Connor, Photographs: Archival Care and Management (Chicago: Society of American Archivists, 2006), 167.

65. "This [Notes] field is used for relevant information that is NOT entered into any of the other fields. It can be used for expanded or explanatory remarks, contextual information, and citations for certain information, such as alternative titles." George Eastman House, "Department of Photography Cataloging Manual," (working manual, Department of Photography George Eastman House, Rochester, New York, updated September 11, 2013$), 41$. 
Revising the Department of Photography TMS catalogue records for Muray's photographic prints and negatives expanded access to his celebrity materials within the Photography Collection at George Eastman House. Furthermore, it achieved the linking of information between the matching images and the variants that were found in the Mss Collection Boxes 125-126, located in the Richard and Ronay Menschel Library.

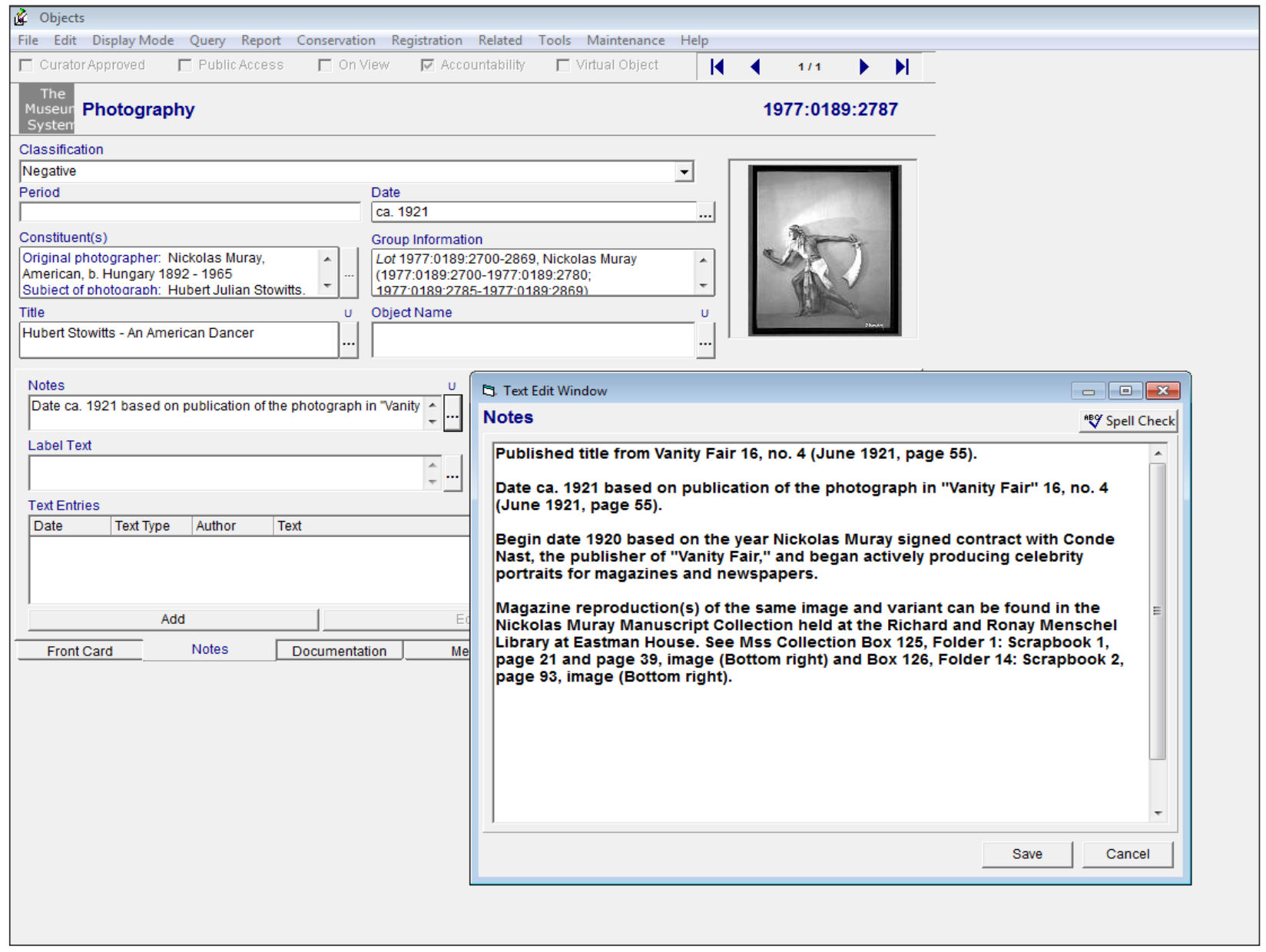

Figure 21. Sample of updated Notes field in TMS, 1977:0189:2787 


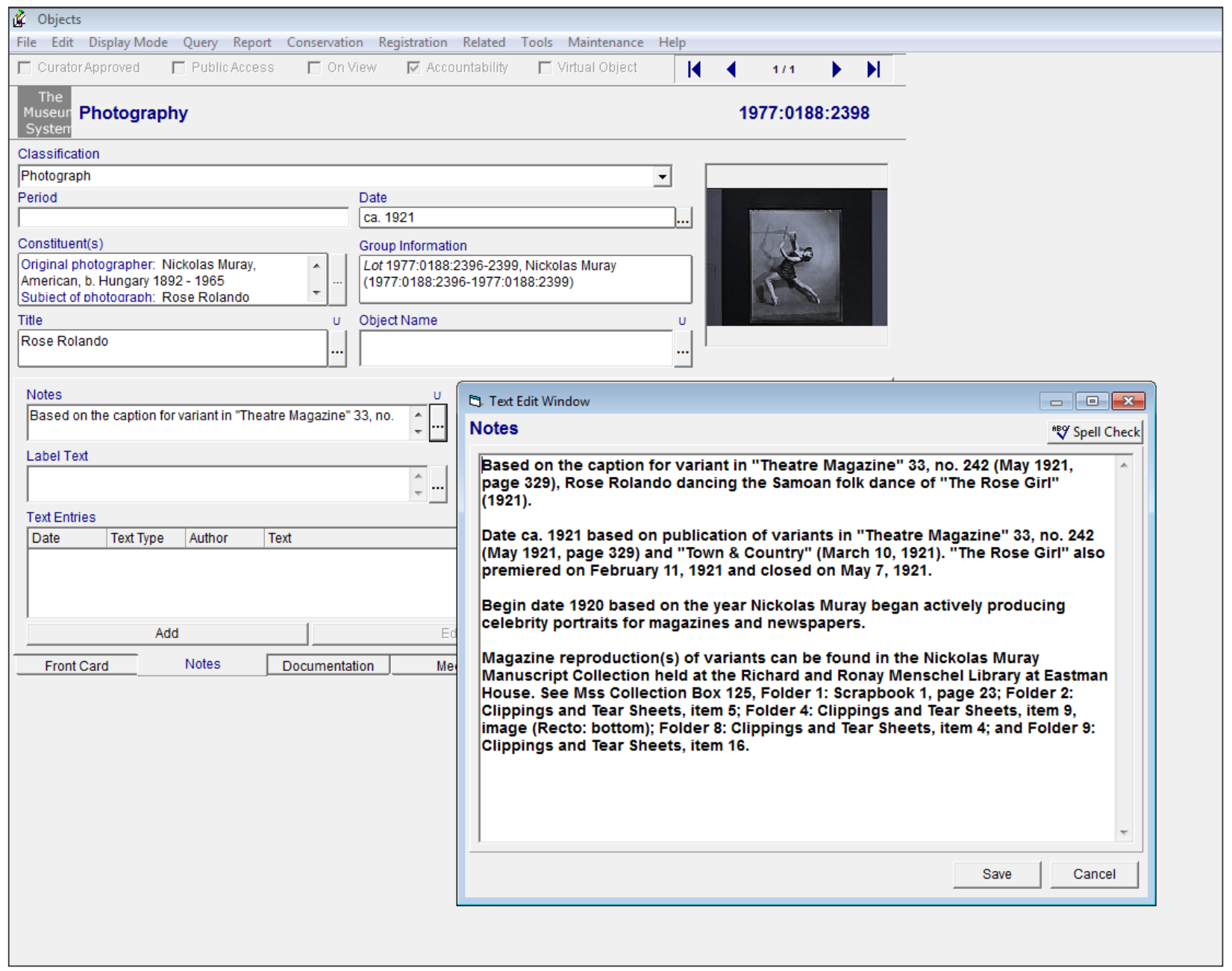

Figure 22. Sample of updated Notes field in TMS, 1977:0188:2398 


\section{Conclusion}

The overarching goal of this applied project was to expand access to Nickolas Muray's celebrity portraits by creating intellectual links between the Richard and Ronay Menschel Library Manuscript (Mss) Collection and the Department of Photography (DOP) Collection at George Eastman House, which have hitherto been managed by the two unrelated cataloguing systems-i.e., Library finding aid and DOP catalogue records in The Museum System (TMS).

The first phase in the linking of the two systems was concerned with processing the Muray celebrity materials within the Library Manuscript Collection. Based on the information attained from the inventory and the data gathering steps (i.e., survey of relevant magazines and identification of matching images and variants between the Manuscript and Photography Collections), I extended the existing Library finding aid for the Nickolas Muray Manuscript Collection and created item-level descriptions for the Mss Collection Boxes 125-126 Nickolas Muray Illustrations. A fundamental understanding of archival principles and practices played a crucial role in developing and implementing the final arrangement for the related manuscript materials and determining appropriate fields in the item-level descriptions.

The second phase consisted of updating the DOP TMS catalogue records for Muray's photographic prints and negatives with corresponding images to those found in the Mss Collection Boxes 125-126 and their variants from the same photographic sessions. Object-based cataloguing of the matching images and variants not only broadened my understanding of the Muray celebrity materials within the DOP Collection, but also established the complete body of work for this applied project. This was followed by updates to the TMS catalogue fields - namely, Published Title, Date, Description, Related Works, and Notes. This paper demonstrated how these TMS fields were used in creating intellectual links between the two unrelated collection materials.

As the literature survey undertaken for this applied project suggests, the Richard and Ronay Menschel Library and the Department of Photography at George Eastman House historically have 
maintained cataloguing systems that are unique to their own fields and traditions. Although the museum holds a large number of Nickolas Muray's celebrity portraits both in the Library Manuscript Collection and the DOP Collection, information pertaining to his celebrity materials had been unrelated in their respective cataloguing systems. Muray's celebrity portraits were, to a large extent, made for hire to be reproduced in magazines and newspapers. Since the Library holds examples of these publications and the DOP TMS catalogue records were missing the information relating to these materials, linking of the two systems was advantageous. Not only did the links expand access to Muray's celebrity portraits in the Library Manuscript Collection, but they also added valuable input to the existing TMS catalogue records for Muray's photographic prints and negatives, which, previous to this project, only included limited information such as digital reproductions of the objects, descriptive titles, and approximate dates of production (for example, ca. 1922-1961).

The large volume of the materials found in the Library's Mss Collection Boxes 125-126 proved that the scope of this applied project must be limited to the processing of information related to Muray's celebrity portraits. This created a need for future processing of his commercial advertising works that were also found in the Mss Collection Boxes 125-126. While the work completed in this project expanded access to Muray's celebrity materials, the methodologies presented in this paper could also be applied to the linking of his commercial advertising works to the matching photographic prints and negatives in the DOP Collection at George Eastman House. The clippings and tear sheets from the Mss Collection Boxes 125-126 exemplify that Muray produced advertising photographs for garments (e.g., Franklin Simon \& Co., Best \& Co. and Bergdorf Goodman), hairstyles (e.g., Manuel), as well as products such as perfume. By creating the full inventory of Muray's manuscript materials (discussed in the section 3.1.2.), I streamlined the procedures for future processing of information related to his commercial works. When that project is addressed, I suggest that magazines such as Vogue, Harper's Bazar and The Ladies' Home Journal be surveyed as identification sources because of their emphasis on fashion trends. Muray's advertising works were also reproduced in newspapers such as The New York Times and New York 
Herald Tribune; thus, these publications should also be considered as primary sources for this future project. The same descriptive fields included in the Library's item-level descriptions for the Mss Collection Boxes 125-126 can be used to relate his commercial advertising works to the corresponding images and their variants in the DOP Collection. Given that the future processing of his commercial works in the Mss Collection Boxes 125-126 determines their publication dates, rearrangement of the disassembled scrapbook pages by date may also be possible. Similarly, the same DOP TMS catalogue fields for the matching images and their variants within the Muray commercial advertising materials in the Photography Collection can be revised following the methodologies adopted in the processing of Muray's celebrity portraits. Moreover, I foresee that my work completed for this project can be applied, in full or in part, to other collections that are related in some way yet managed by different divisions of an institution in their respective cataloguing systems.

By developing and implementing a plan to expand the Library finding aid for the Nickolas Muray Manuscript Collection and by applying the information attained from the Library's manuscript materials to the DOP TMS catalogue records, I achieved the goal of linking the two previously unrelated collections at George Eastman House. As a result, this applied project made the information for both collections accessible to future researchers for, including but not limited to, research, publication and exhibition purposes. George Eastman House and outside researchers can now better understand this renowned photographer, Nickolas Muray, and his celebrity works that deserve much further research and recognition. 
Appendix A: Samples from inventory spreadsheet

\begin{tabular}{|c|c|c|c|c|c|c|c|}
\hline $\begin{array}{c}\text { Page } \\
\#\end{array}$ & Image Location & Subject & $\begin{array}{l}\text { Published } \\
\text { Title }\end{array}$ & Page Title & Date & Original Publication & Scope and Content \\
\hline 1 & (Top) & Edith Roberts & - & - & $\begin{array}{l}\text { circa } 1921 \\
\text { (Date based on } \\
\text { surrounding clippings) }\end{array}$ & Unknown & \\
\hline 1 & (Bottom left) & Mary Blair & - & - & $\begin{array}{l}\text { June } \\
1921\end{array}$ & $\begin{array}{l}\text { Vanity Fair 16, no. } 4 \\
\text { (June } 1921 \text {, page } 46 \text { ) }\end{array}$ & - \\
\hline 1 & (Bottom center) & Patti Harrold & - & - & $\begin{array}{l}\text { circa } 1921 \\
\text { (Date based on caption) }\end{array}$ & Unknown & - \\
\hline 1 & (Bottom right) & $\begin{array}{l}\text { Evan-Burrows } \\
\text { Fontaine }\end{array}$ & $\begin{array}{l}\text { The Soul of } \\
\text { Egypt }\end{array}$ & - & $\begin{array}{l}\text { October } \\
1920\end{array}$ & $\begin{array}{l}\text { Vanity Fair } 15 \text {, no } 2 \\
\text { (October } 1920 \text {, page } \\
78 \text { ) }\end{array}$ & $\begin{array}{l}\text { Based on the caption for } \\
\text { the reproduction, } \\
\text { Evan-Burrows Fontaine } \\
\text { as an Egyptian dancer of } \\
\text { Ed Wynn's Carnival. }\end{array}$ \\
\hline 22 & (Top left) & $\begin{array}{l}\text { Marjorie Jarvis } \\
\text { (Model 48) }\end{array}$ & - & $\begin{array}{l}\text { The Spring } \\
\text { Bramley Coats } \\
\text { and Suits }\end{array}$ & February 1926 & $\begin{array}{l}\text { [Harper's Bazar?] } \\
\text { (February 1926, page } \\
\text { unknown) }\end{array}$ & $\begin{array}{l}\text { Reproduction of } \\
\text { commercial advertising } \\
\text { photograph by Muray } \\
\text { for Franklin Simon \& } \\
\text { Co. }\end{array}$ \\
\hline 22 & (Top right) & $\begin{array}{l}\text { Margaret } \\
\text { Van Winkle } \\
\text { (Model 50) }\end{array}$ & - & $\begin{array}{l}\text { The Spring } \\
\text { Bramley Coats } \\
\text { and Suits }\end{array}$ & February 1926 & $\begin{array}{l}\text { [Harper's Bazar?] } \\
\text { (February 1926, page } \\
\text { unknown) }\end{array}$ & $\begin{array}{l}\text { Reproduction of } \\
\text { commercial advertising } \\
\text { photograph by Muray } \\
\text { for Franklin Simon \& } \\
\text { Co. }\end{array}$ \\
\hline
\end{tabular}

Table 1. Sample from spreadsheet: scrapbooks

Mss Collection Box 125, Folder 1: Scrapbook 1, page 1 and Box 126, Folder 14: Scrapbook 2, page 220

i. The page number 22 was assigned temporarily for inventory purposes; in the Richard and Ronay Menschel Library's item-level descriptions for the Mss Collection Boxes 125-126 Nickolas Muray Illustrations, the reproductions from this page can be found under Box 126, Folder 14: Scrapbook 2, page 220. 


\begin{tabular}{|c|c|c|c|c|c|c|c|}
\hline $\begin{array}{c}\text { Item } \\
\#\end{array}$ & Image Location & Subject & $\begin{array}{l}\text { Published } \\
\text { Title }\end{array}$ & Page Title & Date & Original Publication & Scope and Content \\
\hline 1 & - & $\begin{array}{l}\text { Florence } \\
\text { O’Denishawn }\end{array}$ & - & - & January 1921 & $\begin{array}{l}\text { Harper's Bazar 56, no. } 1 \\
\text { (January 1921, page 62) }\end{array}$ & $\begin{array}{l}\text { Based on the caption } \\
\text { for the reproduction, } \\
\text { Florence O'Denishawn } \\
\text { dancing Raymond } \\
\text { Hitchcock's Hitchy } \\
\text { Koo. }\end{array}$ \\
\hline 2 & (Left) & Desha Delteil & - & $\begin{array}{l}\text { Modern } \\
\text { Exponents of a } \\
\text { Most Ancient Art }\end{array}$ & April 1921 & $\begin{array}{l}\text { Vanity Fair 16, no, } 2 \\
\text { (April 1921, page 45) }\end{array}$ & - \\
\hline 2 & (Right) & $\begin{array}{l}\text { Florence } \\
\text { O’Denishawn }\end{array}$ & - & $\begin{array}{l}\text { Modern } \\
\text { Exponents of a } \\
\text { Most Ancient Art }\end{array}$ & April 1921 & $\begin{array}{l}\text { Vanity Fair 16, no, } 2 \\
\text { (April 1921, page 45) }\end{array}$ & - \\
\hline
\end{tabular}

Table 2. Sample from spreadsheet: clippings and tear sheets-The highlighted field indicates where item numbers were recorded in place of page numbers. ${ }^{\text {ii }}$

\begin{tabular}{|c|c|c|c|c|c|c|c|c|}
\hline $\begin{array}{c}\text { Item } \\
\#\end{array}$ & & ge Location & Subject & $\begin{array}{c}\text { Published } \\
\text { Title }\end{array}$ & Page Title & Date & $\begin{array}{c}\text { Original } \\
\text { Publication }\end{array}$ & Scope and Content \\
\hline \multirow[t]{8}{*}{155} & Page & Image & \multirow{8}{*}{$\begin{array}{l}\text { Unidentified } \\
\text { Unidentified } \\
\text { Unidentified } \\
\text { Jacky Hurlburt } \\
\text { Harry Kemp } \\
\text { Bobby Edwards } \\
\text { Ilonka Karasz }\end{array}$} & \multirow{8}{*}{$\begin{array}{l}- \\
- \\
- \\
- \\
- \\
- \\
-\end{array}$} & \multirow{8}{*}{$\begin{array}{l}- \\
- \\
\text { The New Art of Camera Painting } \\
\text { The New Art of Camera Painting } \\
\text { In Greenwich Village } \\
\text { In Greenwich Village } \\
\text { In Greenwich Village }\end{array}$} & \multirow{8}{*}{$\begin{array}{l}\text { July } \\
1920\end{array}$} & \multirow{8}{*}{$\begin{array}{l}\text { Shadowland 2, no. } \\
11 \text { (July 1920) }\end{array}$} & \multirow{8}{*}{$\begin{array}{l}\text { The magazine also } \\
\text { contains Dorothy } \\
\text { Donnell's essay, "The } \\
\text { New Art of Camera } \\
\text { Painting," in which } \\
\text { Donnell discusses } \\
\text { Muray's portrait } \\
\text { photography and his } \\
\text { studio in Greenwich } \\
\text { Village. }\end{array}$} \\
\hline & 14 & (Top) & & & & & & \\
\hline & 14 & (Bottom) & & & & & & \\
\hline & 15 & (Top) & & & & & & \\
\hline & 15 & (Bottom) & & & & & & \\
\hline & 27 & (Top) & & & & & & \\
\hline & 27 & (Bottom left) & & & & & & \\
\hline & 27 & (Bottom right) & & & & & & \\
\hline
\end{tabular}

Table 3. Sample from spreadsheet: miscellaneous magazine periodicals-The highlighted field indicates where the additional notes on the locations of Muray's reproductions within the magazines were recorded.

ii. The item numbers in Table 2 and Table 3 were assigned temporarily for inventory purposes; they do not reflect the final item numbers in the Library's item-level descriptions for the Mss Collection Boxes 125-126 Nickolas Muray Illustrations. For the final item numbers, see "Finding Aid for the Nickolas Muray Manuscript Collection," held in the Richard and Ronay Menschel Library at George Eastman House. 


\begin{tabular}{|c|c|c|c|c|c|c|}
\hline Subject & $\begin{array}{c}\text { Published } \\
\text { Title }\end{array}$ & $\begin{array}{l}\text { Page } \\
\text { Title }\end{array}$ & Date & Original Publication & Scope and Content & Related Materials \\
\hline Florence Reed & - & - & $\begin{array}{l}\text { December } \\
1920\end{array}$ & $\begin{array}{l}\text { Harper's Bazar 55, } \\
\text { no. } 12 \text { (December } \\
1920, \text { page } 56 \text { ) }\end{array}$ & - & $\begin{array}{l}\text { Gelatin silver print(s) and cellulose nitrate } \\
\text { negative of the matching image and variants } \\
\text { also available in the Photography Collection at } \\
\text { The Gannet Foundation Photographic Study } \\
\text { Center, located in George Eastman House, } \\
\text { with the following accession numbers: } \\
\text { 1971:0044:0016, 1977:0188:2315, } \\
\text { 1877:0188:2317, 1977:0188:2318, } \\
\text { 1977:0188:2319, 1977:0188:2321, } \\
\text { 1977:0189:2315, 1977:0189:2317, } \\
\text { 1977:0189:2318, 1977:0189:2319, and } \\
\text { 1977:0189:2321. }\end{array}$ \\
\hline $\begin{array}{l}\text { Hubert Julian } \\
\text { Stowitts }\end{array}$ & $\begin{array}{l}\text { Hubert } \\
\text { Stowitts-An } \\
\text { American } \\
\text { Dancer }\end{array}$ & - & June 1921 & $\begin{array}{l}\text { Vanity Fair } 16, \text { no. } 4 \\
\text { (June } 1921 \text {, page } 55 \text { ) }\end{array}$ & - & $\begin{array}{l}\text { Gelatin silver print and cellulose nitrate } \\
\text { negative of the matching image and variants } \\
\text { also available in the Photography Collection at } \\
\text { The Gannet Foundation Photographic Study } \\
\text { Center, located in George Eastman House, } \\
\text { with the following accession numbers: } \\
\text { 1971:0045:0024, 1977:0189:2787, } \\
\text { 1977:0189:2788, and 1977:0664:0026. }\end{array}$ \\
\hline Rose Rolanda & - & - & $\begin{array}{l}\text { circa } 1921 \\
\text { (Date based } \\
\text { on caption) }\end{array}$ & $\begin{array}{l}\text { Cosmopolitan (date } \\
\text { unknown, page } 52 \text { ) }\end{array}$ & $\begin{array}{l}\text { Based on the caption for } \\
\text { the reproduction, Rose } \\
\text { Rolanda dancing the } \\
\text { Samoan "gold stick" } \\
\text { folk-dance of The Rose } \\
\text { Girl (1921). }\end{array}$ & $\begin{array}{l}\text { Gelatin silver print of variants also available in } \\
\text { the Photography Collection at The Gannet } \\
\text { Foundation Photographic Study Center, } \\
\text { located in George Eastman House, with the } \\
\text { following accession numbers: } \\
\text { 1971:0035:0067, 1971:0035:0092, and } \\
\text { 1977:0188:2398. }\end{array}$ \\
\hline
\end{tabular}

Table 4. Sample from spreadsheet: links between the Library manuscript materials and the Department of Photography Collection-The highlighted field indicates where the Department of Photography accession numbers for Muray's photographic prints and negatives with the corresponding images and their variants were entered. iil $^{\text {il }}$

iii. See Mss Collection Box 125, Folder 1: Scrapbook 1, pages 18, 21, and 23 in the Library's item-level descriptions for the Mss Collection Boxes 125-126 Nickolas Muray Illustrations for more information. 


\begin{tabular}{|c|c|c|c|c|c|c|}
\hline Subject & $\begin{array}{c}\text { Published } \\
\text { Title }\end{array}$ & $\begin{array}{l}\text { Page } \\
\text { Title }\end{array}$ & Date & Original Publication & \multicolumn{1}{|c|}{ Scope and Content } & \multicolumn{1}{|c|}{ Related Materials } \\
\hline Rose Rolanda & - & - & $\begin{array}{l}\text { circa 1921 } \\
\text { (Date based } \\
\text { on caption) }\end{array}$ & $\begin{array}{l}\text { Cosmopolitan (date } \\
\text { unknown, page 52) }\end{array}$ & $\begin{array}{l}\text { Based on the caption for } \\
\text { the reproduction, Rose } \\
\text { Rolanda dancing the } \\
\text { Samoan "gold stick" } \\
\text { folk-dance of The Rose } \\
\text { Girl (1921). }\end{array}$ & $\begin{array}{l}\text { See also Box 125, Folder 1: Scrapbook 1, page } \\
\text { 53; Folder 2: Clippings and Tear Sheets, item } \\
\text { 5; Folder 4: Clippings and Tear Sheets, item 9, } \\
\text { images (Recto: top) and (Recto: bottom) and } \\
\text { item 10, image (Recto); Folder 8: Clippings } \\
\text { and Tear Sheets, item 4; and Folder 9: } \\
\text { Clippings and Tear Sheets, item 16. }\end{array}$ \\
& & & & & $\begin{array}{l}\text { Gelatin silver print of variants also available in } \\
\text { the Photography Collection at The Gannet } \\
\text { Foundation Photographic Study Center, } \\
\text { located in George Eastman House, with the } \\
\text { following accession numbers: } \\
1971: 0035: 0067,1971: 0035: 0092, \text { and } \\
1977: 0188: 2398 .\end{array}$ \\
\hline
\end{tabular}

Table 5. Sample from spreadsheet: links between related Library manuscript materials within the Mss Collection Boxes 125-126-The highlighted area indicates where the locations of related manuscript materials were entered. ${ }^{\text {iv }}$

iv. See Mss Collection Box 125, Folder 1: Scrapbook 1, page 23 in the Library's item-level descriptions for the Mss Collection Boxes 125-126 Nickolas Muray Illustrations for more information. 
Appendix B: Samples from item-level descriptions for the Nickolas Muray Manuscript (Mss) Collection Boxes 125-126 Illustrations ${ }^{\mathrm{v}}$

\section{Box 125 \\ Folder 1: (Scrapbook 1) circa 1920-1927, bulk 1921-1922 and 1924-1925}

Page 1

(Top)

(Bottom left)

(Bottom center)

(Bottom right)

Page 2

(Top)

(Bottom left)
Subject: Edith Roberts

Date: circa 1921 (Date based on surrounding clippings)

Original Publication: Unknown

Related Materials: None

Subject: Mary Blair

Date: June 1921

Original Publication: Vanity Fair 16, no. 4 (June 1921, page 46)

Related Materials: None

Subject: Patti Harrold

Date: circa 1921(Date based on caption)

Original Publication: Unknown

Related Materials: See also Box 125, Folder 4: Clippings and Tear Sheets, item 8, images (Recto: top left) and (Recto: bottom right) and Folder 11: Clippings and Tear Sheets, item 11.

\begin{abstract}
Subject: Evan-Burrows Fontaine
Published Title: The Soul of Egypt

Date: October 1920

Original Publication: Vanity Fair 15, no 2 (October 1920, page 78)

Scope and Content: Based on the caption for the reproduction, Evan-Burrows Fontaine as an Egyptian dancer of Ed Wynn's Carnival (1920).

Related Materials: See also Box 125, Folder 1: Scrapbook 1, page 4, image (bottom right); page 12, images (Top left) and (Top right); page 13, image (Top left); and page 50, image (Top); Folder 8: Clippings and Tear Sheets, item 1; and Folder 10: Clippings and Tear Sheets, item 1, images (Top left) and (Bottom right) and item 2.
\end{abstract}

Subject: Mary Miles Minter

Published Title: The Spirit of Spring

Date: circa 1921 (Date based on surrounding clippings)

Original Publication: Unknown

Related Materials: See also Box 125, Folder 1: Scrapbook 1, page 3, image (Top).

Subject: Unidentified

Date: circa 1921 (Date based on surrounding clippings)

Original Publication: Unknown

Related Materials: None

Figure 23. Sample from item-level descriptions: Scrapbook 1

v. For the entire item-level descriptions for the Mss Collection Boxes 125-126 Nickolas Muray Illustrations, see "Finding Aid for the Nickolas Muray Manuscript Collection," held in the Richard and Ronay Menschel Library at George Eastman House. 


\section{Box 125}

Folder 3: (Clippings and Tear Sheets_Vanity Fair) 1921, 1925, and 1927

\section{Item 1:}

\section{Subject: Elsie Mackay}

Date: March 1921

Original Publication: Vanity Fair 16, no, 1 (March 1921, page 39)

Scope and Content: Based on the caption for the reproduction, Elsie Mackay as Marie Duplessis of Sacha Guitry's Deburau (1921).

Related Materials: See also Box 125, Folder 2: Clippings and Tear Sheets, item 4, image (Bottom); Folder 3: Clippings and Tear Sheets, item 5; Folder 4: Clippings and Tear Sheets, item 12; and Folder 6: Clippings and Tear Sheets, item 8.

Item 2:

\section{Subject: Pauline Lord}

Date: April 1921

Original Publication: Vanity Fair 16, no, 2 (April 1921, page 42)

Related Materials: None

Item 3:

\section{Subject: Lionel Atwill}

Date: April 1921

Original Publication: Vanity Fair 16, no, 2 (April 1921, page 42)

Scope and Content: Based on the caption for the reproduction, Lionel Atwill as the Pierrot Jean-Gaspard Deburau of Deburau (1920-1921).

Related Materials: See also Box 125, Folder 1: Scrapbook 1, page 26, image (Top) and page 82, image (Top left) and Box 125, Folder 6: Clippings and Tear Sheets, item 8. Gelatin silver print and cellulose nitrate negative of variants also available in the Photography Collection at The Gannett Foundation Photographic Study Center, located in George Eastman House, with the following accession numbers: 1977:0188:0169 and 1977:0189:0170.

\section{Item 4:}

(Left)

Subject: Desha Delteil

Published Title: Desha

Page Title: Modern Exponents of a Most Ancient Art

Date: April 1921

Original Publication: Vanity Fair 16, no, 2 (April 1921, page 45)

Related Materials: None

(Right) Subject: Florence O'Denishawn

Page Title: Modern Exponents of a Most Ancient Art

Date: April 1921

Original Publication: Vanity Fair 16, no, 2 (April 1921, page 45)

Related Materials: See also Box 125, Folder 6: Clippings and Tear Sheets, item 6, image (Bottom left).

Figure 24. Sample from item-level descriptions: Clippings and Tear Sheets 


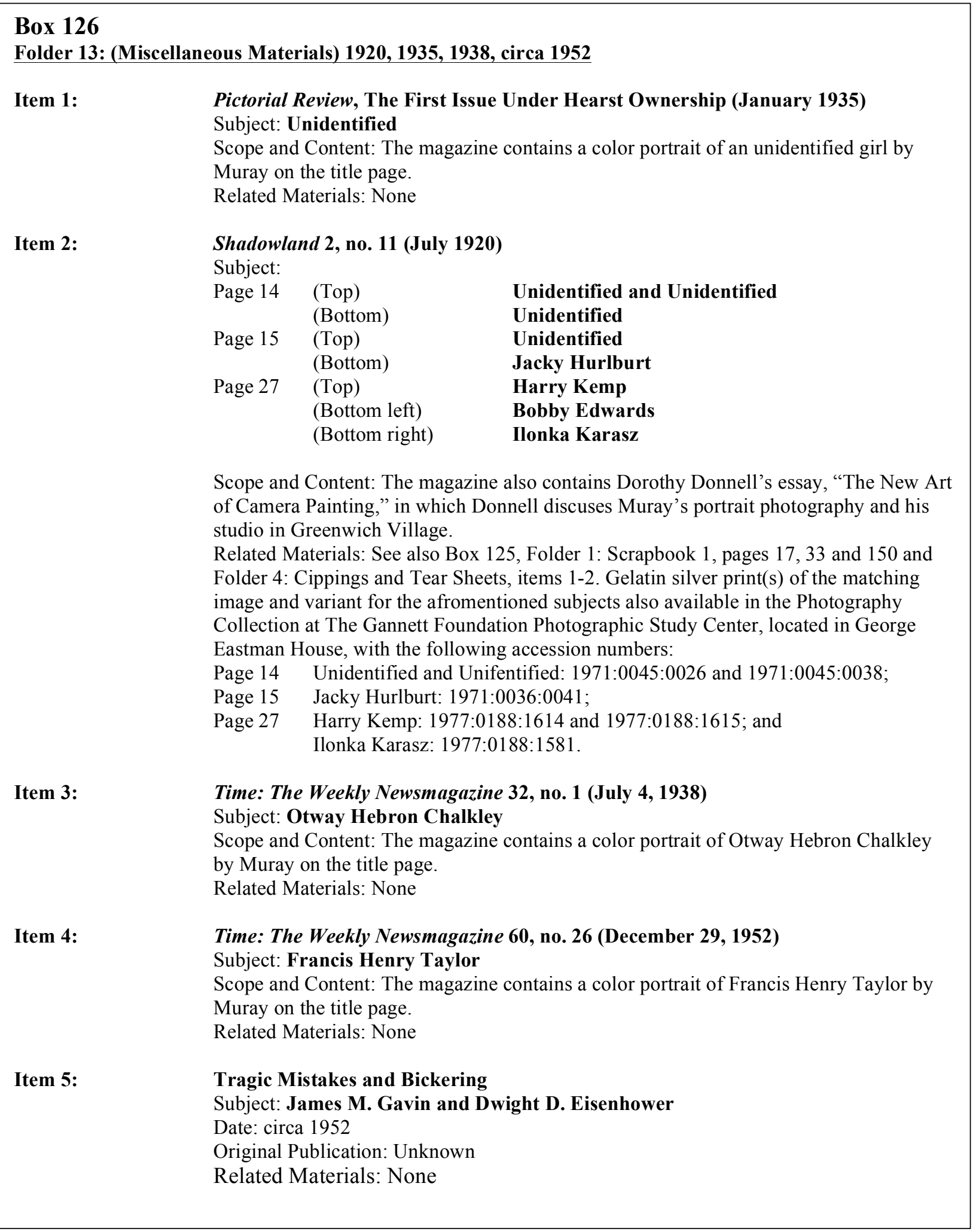

Figure 25. Sample from item-level descriptions: Miscellaneous Materials 


\section{Box 126 \\ Folder 14: (Scrapbook 2) circa 1921-1927, bulk 1922, 1924-1925}

\section{Page 1:}

(Top left)

(Top right)

(Middle left)

(Middle right)

(Bottom)

Page 2:
Subject: Maurice Schwarz

Date: July 1922

Original Publication: Vanity Fair 18, no. 4 (July 1922, page 38)

Related Materials: See also Box 125, Folder 1: Scrapbook 1, page 95, image (Bottom left). Gelatin silver print of the matching image and variants also available in the Photography Collection at The Gannett Foundation Photographic Study Center, located in George Eastman House, with the following accession numbers: 1977:0188:2607, 1977:0188:2608, and1977:0188:2609.

\section{Subject: Celia Adler}

Date: July 1922

Original Publication: Vanity Fair 18, no. 4 (July 1922, page 38)

Related Materials: See also Box 125, Folder 1: Scrapbook 1, page 95, image (Top left).

\section{Subject: Jacob Ben Ami}

Date: July 1922

Original Publication: Vanity Fair 18, no. 4 (July 1922, page 38)

Related Materials: Gelatin silver print and cellulose nitrate negative of the matching image and variants also available in the Photography Collection at The Gannett Foundation Photographic Study Center, located in George Eastman House, with the following accession numbers: 1971:0043:0011, 1977:0188:0041, 1977:0188:0043, 1977:0188:0044, 1977:0188:0045, 1977:0189:0041, 1977:0189:0043, 1977:0189:0044, and 1977:0189:0045.

\section{Subject: Giovanni Grasso}

Date: July 1922

Original Publication: Vanity Fair 18, no. 4 (July 1922, page 38)

Related Materials: See also Box 125, Folder 1: Scrapbook 1, page 65, image (Top) and page 95, image (Bottom right). Gelatin silver print of the matching image also available in the Photography Collection at The Gannett Foundation Photographic Study Center, located in George Eastman House, with the following accession number: 1971:0045:0072.

\section{Subject: Jacob Adler}

Date: July 1922

Original Publication: Vanity Fair 18, no. 4 (July 1922, page 38)

Related Materials: See also Box 125, Folder 1: Scrapbook 1, page 95, image (Middle right) and Box 126, Folder 14: Scrapbook 2, page 12, image (Bottom). Gelatin silver prints and cellulose nitrate negative of the matching image and variants also available in the Photography Collection at The Gannett Foundation Photographic Study Center, located in George Eastman House, with the following accession numbers: 1971:0043:0029, 1971:0043:0030, 1977:0188:0014A-B, 1977:0188:0016, 1977:0189:0014, 1977:0189:0015, 1977:0189:0016, 1977:0189:0017, 1977:0189:0018, 1977:0189:0019, and 1977:0189:0020.

Empty page with traces of previous clippings

Figure 26. Sample from item-level descriptions: Scrapbook 2 
Appendix C: Samples of object-based The Museum System (TMS) catalogue records for the Department of Photography Collection ${ }^{\mathrm{vi}}$

\section{Dimension field}

For all photographic prints, the Dimension fields were first updated during the object-based cataloguing phase. $^{\text {vii }}$

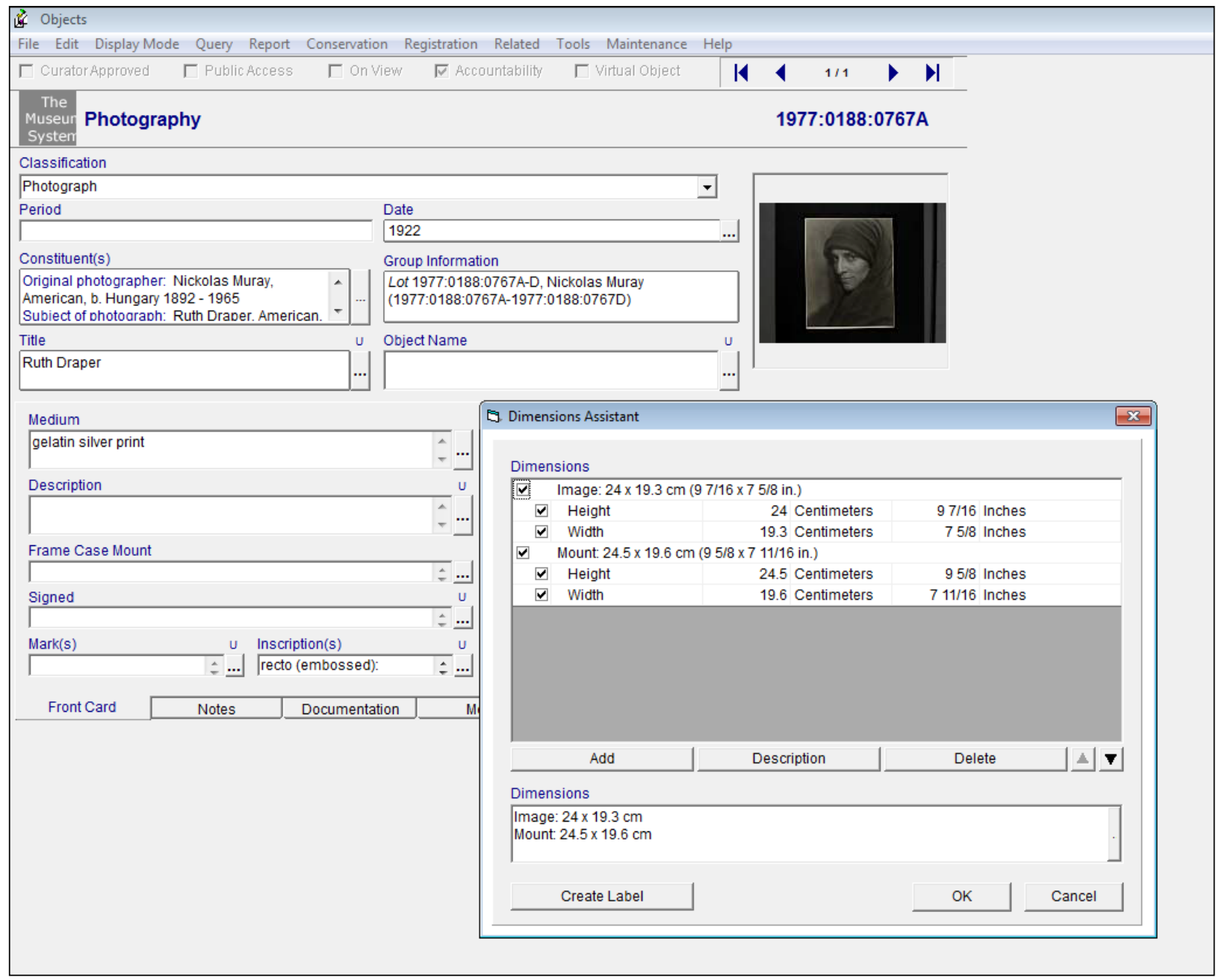

Figure 27. Sample of object-based TMS catalogue records: Dimension field

vi. For the entire TMS catalogue records updated for this applied project, consult the Department of Photography at George Eastman House.

vii. Prior to this applied project, the Dimension fields for most of the photographic prints were entered generically as " 10 x 8 in." or " 14 x 11 in." 


\section{Inscription field}

Second, inscriptions from both recto and verso of the photographic prints were entered in the Inscription field. ${ }^{\text {viii }}$

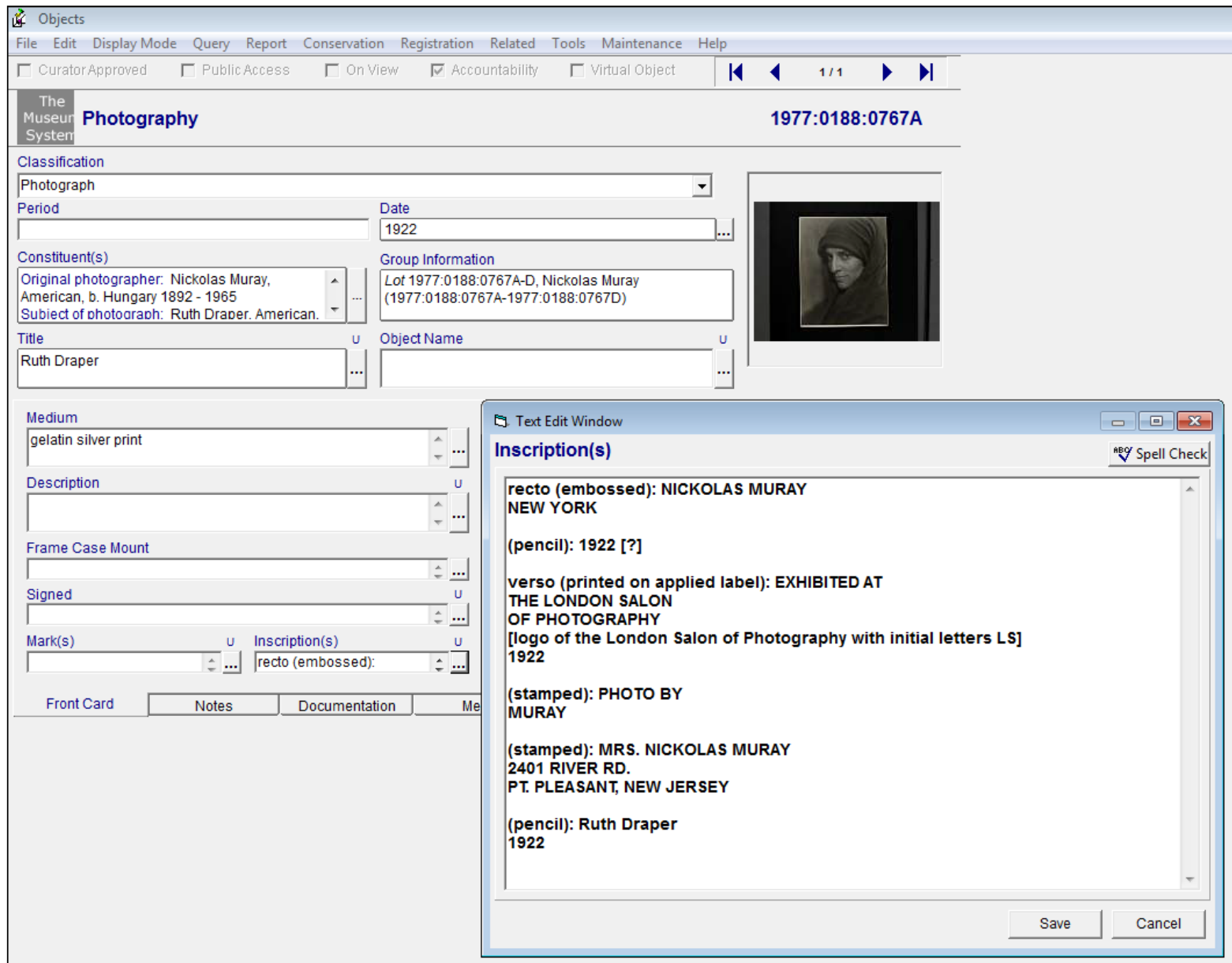

Figure 28. Sample of object-based TMS catalogue records: Inscription field

viii. Prior to this project, the Inscription fields for most of the photographic prints were left blank. 


\section{Title on Object field}

Next, based on the information attained from the Inscription field, the Title on Object field was updated. ${ }^{\text {ix }}$

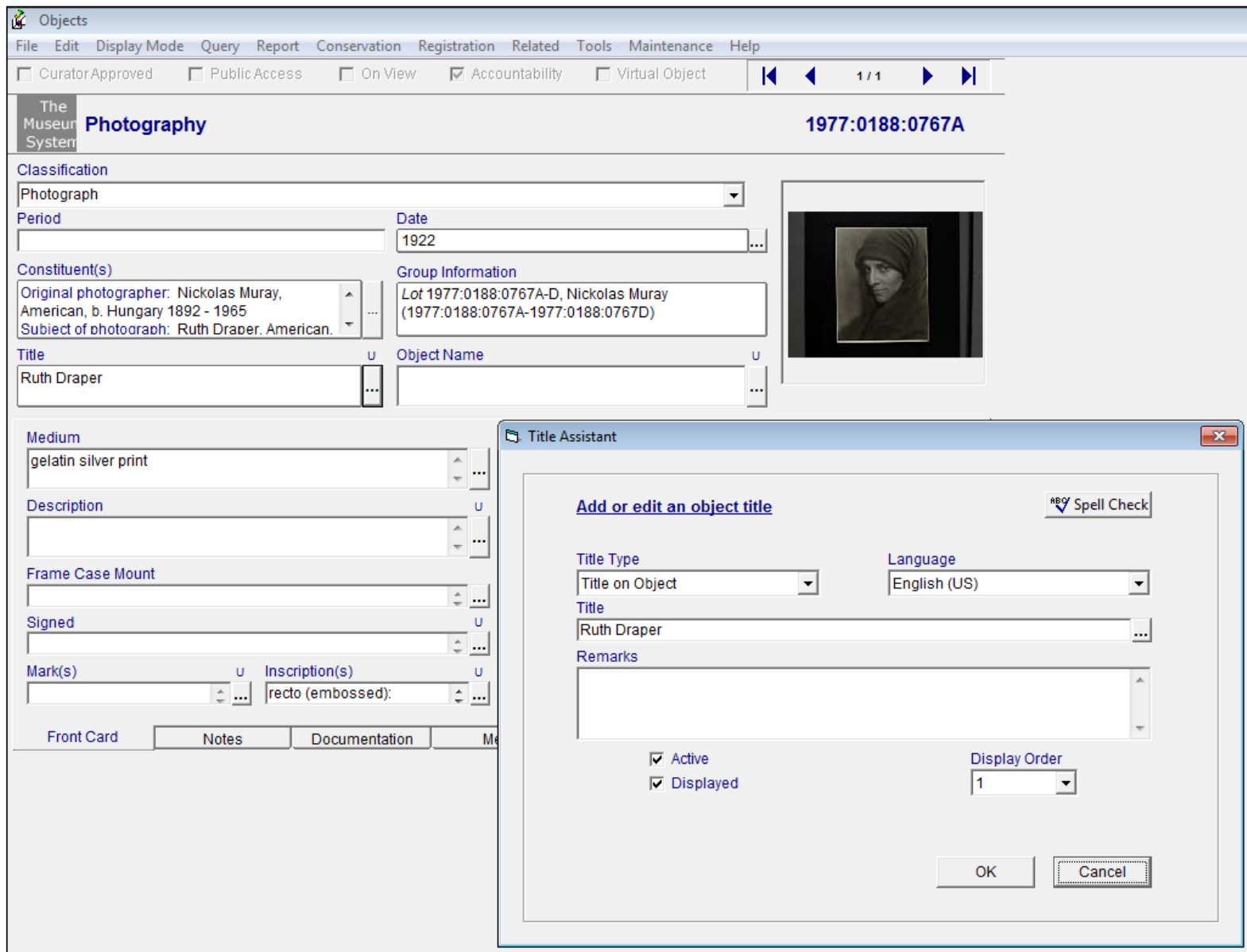

Figure 29. Sample of object-based TMS catalogue records: Title on Object field

ix. Prior to this project, the Title field for most of the photographic prints contained only descriptive titles. 
Date field

Finally, the Date field was revised according to the information in the Inscription field. ${ }^{\mathrm{x}}$

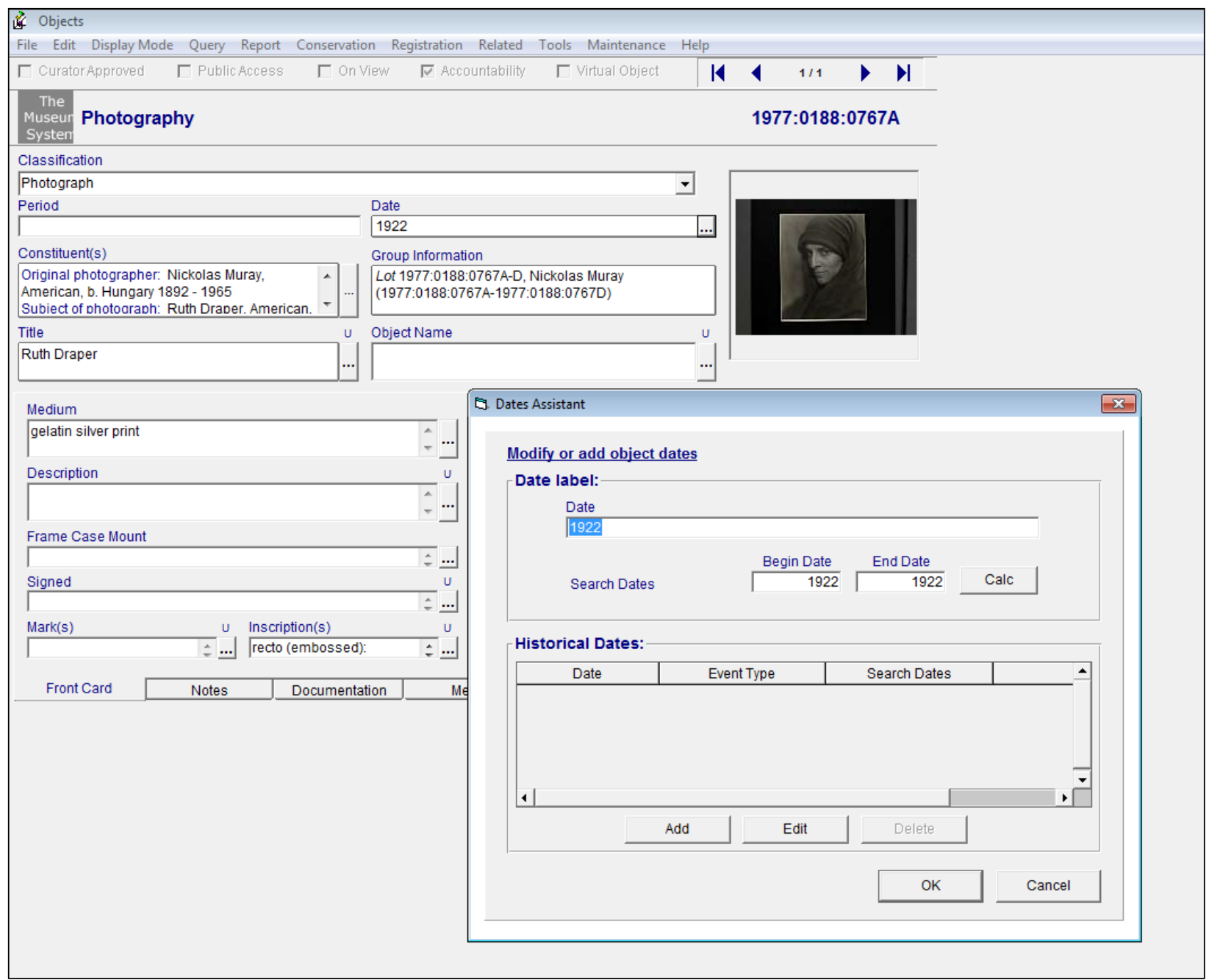

Figure 30. Sample of object-based TMS catalogue records: Date field

x. Prior to this applied project, the Date field for most of the photographic prints contained only approximate dates of production, for example, ca. 1922-1961. 
Appendix D: Flow chart for determining dates of production for Nickolas Muray's photographic prints and negatives

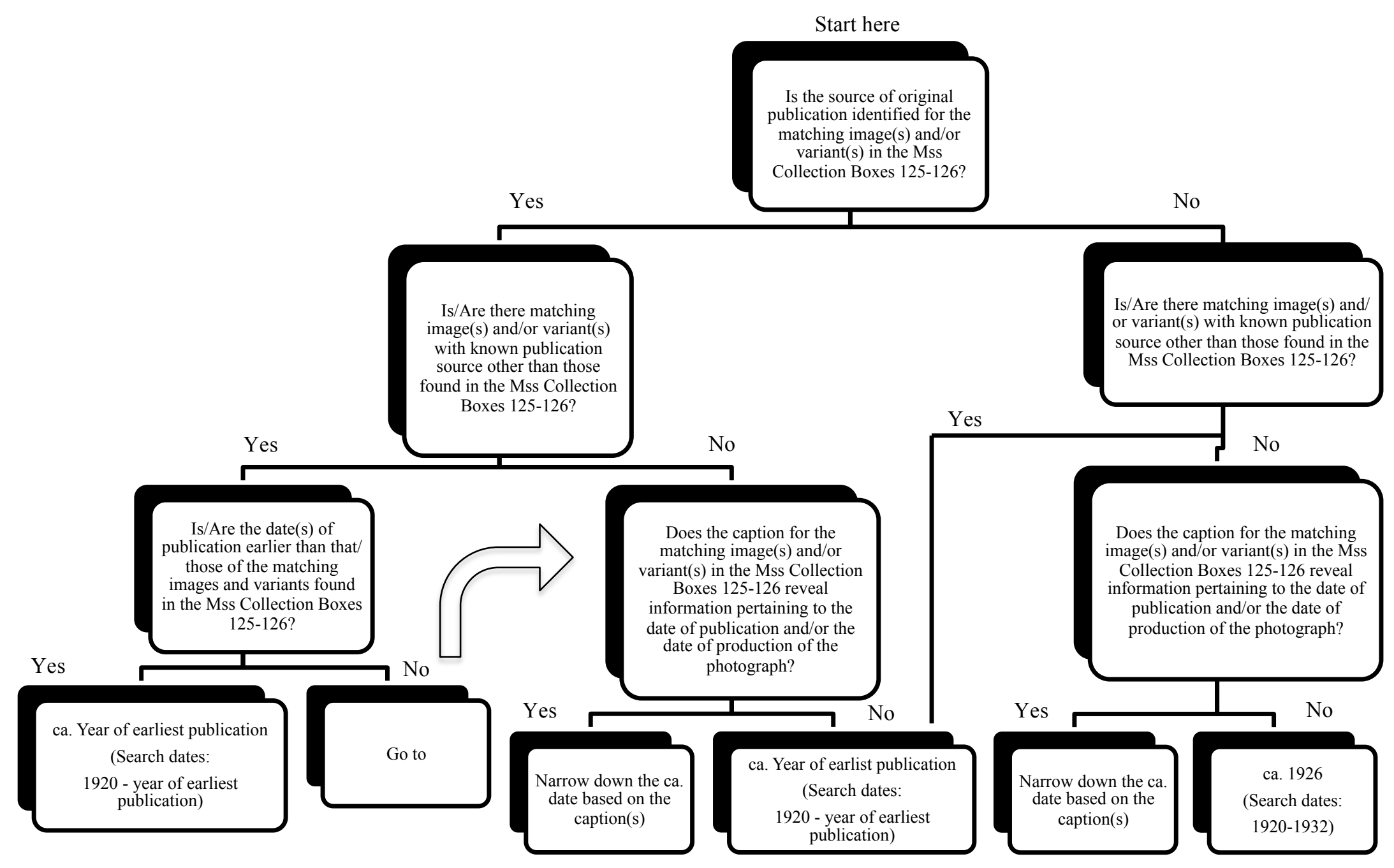




\section{Bibliography}

\section{Magazines and Journals}

All of the magazines and journals consulted for this applied project are listed. Those accessed in libraries are annotated with the identification of the respective locations of consultation.

American Photography. Boston: American Photographic Publishing, January 1923-December 1924.

[Accessed at the Richard and Ronay Menschel Library at George Eastman House]

Camera. Philadelphia: Frank V. Chambers, January 1923-December 1924.

[Accessed at the Richard and Ronay Menschel Library at George Eastman House]

Harper's Bazar. New York: International Magazine Company, January 1920-December 1922. Microfilm. [Accessed at the New York Public Library]

Harper's Bazar. Facsimile edition. New York: International Magazine Company, January-December 1923, January-June 1926, January 1927-December 1932.

[Accessed at the New York Public Library]

Motion Picture Classic. Brooklyn: Brewster Publications, January 1920-July 1925, September 1925, November-December 1925, February 1926-July 1927, October-November 1927, June 1928, August 1928-August 1929, October-November 1929, January 1930-December 1932. Selective issues now declassified and also available online, http://mediahistoryproject.org/collections/. [Other selective issues also accessed at the Toronto Reference Library and the Richard and Ronay Menschel Library at George Eastman House]

Motion Picture Magazine. Brooklyn: Brewster Publications, January-April 1920, December 1920, April-May 1922, September-October 1923, February 1924, May 1928, July 1928-June 1929, March-April 1930, July 1930-April 1931. Selective issues now declassified and also available online, http://mediahistoryproject.org/collections/.

[Other selective issues also accessed at the Toronto Reference Library and the Richard and Ronay Menschel Library at George Eastman House]

Shadowland. Brooklyn: Brewster Publications, January-February 1920, July 1920, September 1922-August 1923. Selected issues now declassified and also available online, http://mediahistoryproject.org/collections/.

Theatre Magazine. Facsimile edition. New York: Theatre Magazine Company, January 1920-April 1931. [Accessed at the Toronto Reference Library]

Vanity Fair. Facsimile edition. Ann Arbor, Mich.: University Microfilms, 1966. First published January 1920-December 1932 by Condé Nast Publications.

[Accessed at the Toronto Reference Library]

Vogue. New York: Condé Nast Publications, January 1, 1920-December 15, 1932. ProQuest 


\section{Nickolas Muray}

Alberts, Heather. "The Figure as Sculptural Form." 1983. George Eastman House Information File: Nickolas Muray. Richard and Ronay Menschel Library, Rochester, New York.

Bynoe, Charmaine. "Finding Africa: An Access Guide to Nickolas Muray's The Great Tribes of Africa Collection at George Eastman House.” Master's thesis, Ryerson University and George Eastman House International Museum of Photography and Film, 2012. http://digitalcommons.ryerson.ca/dissertations/1277.

Donnell, Dorothy. “The New Art of Camera Painting.” Shadowland, July 1920.

Du Pont, Corser. "Nickolas Muray: Environmental Portraiture, Vanity Fair.” Master's thesis, Ryerson University and George Eastman House International Museum of Photography and Film, 2010. http://digitalcommons.ryerson.ca/dissertations/1315.

Fulton Margolis, Marianne. Muray's Celebrity Portraits of the Twenties and Thirties: 135 Photographs by Nickolas Muray. New York: Dover Publications, 1978.

Gallico, Paul. The Revealing Eye: Personalities of the 1920's in Photographs by Nickolas Muray and Words by Paul Gallico. New York: Atheneum, 1967.

Grimberg, Salomon. I Will Never Forget You.... Frida Kahlo \& Nickolas Muray, Unpublished Photographs and Letters. San Francisco: Chronicle Books, 2006.

Muray, Nickolas. “On the Portrait.” In John Wallace Gillies’ Principles of Pictorial Photography, 41-47. New York: Arno Press, 1973.

Nickolas Muray. New York: International Museum of Photography at George Eastman House, 1974. Published in conjunction with the exhibition of the same name, shown at the International Museum of Photography at George Eastman House in Rochester, New York.

Nickolas Muray: Photographs From the Negative Archives of the George Eastman House. Text by Gordon Lewis, 1985. Published in conjunction with the exhibition of the same name, shown at the Boston Athenaeum in Boston, Massachusetts.

Suna and Inan Kiraç Foundation, Pera Museum. Nickolas Muray: bir fotoğrafçinin portresi=Portrait of a Photographer. Istanbul: Pera Museum Publication, 2013.

\section{Expanding Access to Library Manuscript and Museum Collections}

Betz, Elizabeth W. Graphic Materials: Rules for Describing Original Items and Historical Collections. Washington, D.C.: Library of Congress, 1982. http://www.loc.gov/rr/print/gm/GraMatWP8.pdf.

Buck, Rebecca A. and Jean Allman Gilmore, eds. MRM5: Museum Registration Methods. 5th ed. Washington, D.C.: AAM Press, American Association of Museums, 2010. 
Carnell, Brett. “Accessioning and Arrangement.” In Mary Lynn Ritzenthaler and Diane Vogt-O’Connor, Photographs: Archival Care and Management. Chicago: Society of American Archivists, 2006, $135-165$.

Dudley, Kristin E. “A Finding Aid for the Models' Guild of Philadelphia Papers.” Finding aid. Sipley Collection. Richard and Ronay Menschel Library, George Eastman House International Museum of Photography and Film.

“A Finding Aid for the Models' Guild of Philadelphia Papers.” Master's thesis, Ryerson University and George Eastman House International Museum of Photography and Film, 2008. http://digitalcommons.ryerson.ca/dissertations/1086.

George Eastman House. "Department of Photography Cataloging Manual.” Working Manual, Department of Photography, George Eastman House, Rochester, New York, updated September 11, 2013.

Lutek, Tasha. "The Specimens Box: A Case Study in Cataloguing at George Eastman House.” Master's thesis, Ryerson University and George Eastman House International Museum of Photography and Film, 2010.

http://digitalcommons.ryerson.ca/cgi/viewcontent.cgi?article=2227\& context=dissertations.

Ritzenthaler, Mary Lynn. "Copying and Duplication.” In Mary Lynn Ritzenthaler and Diane Vogt-O'Connor, Photographs: Archival Care and Management. Chicago: Society of American Archivists, 2006, 350-375.

Roe, Kathleen D. Arranging \& Describing Archives \& Manuscripts. Chicago: Society of American Archivists, 2005.

Shaw, Meghan. "Processing Edward Steichen's Celebrity Portrait Photographs at George Eastman House." Master's thesis, Ryerson University and George Eastman House International Museum of Photography and Film, 2013.

Simmons, Becky. "Nickolas Muray Manuscript Collection.” Finding aid. Richard and Ronay Menschel Library, George Eastman House International Museum of Photography and Film.

Smith, Amanda L. "Providing Access to the Everette Dixie Reese Prints and Negatives at the George Eastman House.” Master's thesis, Ryerson University and George Eastman House International Museum of Photography and Film, 2011. http://digitalcommons.ryerson.ca/dissertations/1767.

Society of American Archivists. Describing Archives: A Content Standard. 2nd ed. Chicago: Society of American Archivists, 2013. http://files.archivists.org/pubs/DACS2E-2013.pdf.

Zinkham, Helena. "Description and Cataloging.” In Mary Lynn Ritzenthaler and Diane Vogt-O'Connor, Photographs: Archival Care and Management. Chicago: Society of American Archivists, 2006, 164-206.

\section{Miscellaneous}

Carter, Graydon. Vanity Fair, The Portraits: A Century of Iconic Images. New York: Abrams, 2008.

Cornyn, Stan. A Selective Index to Theatre Magazine, New York: Scarecrow Press, 1964. 
Drowne, Kathleen Morgan, and Patrick Huber. The 1920s. Westport, Connecticut: Greenwood Press, 2004.

Foster, Sheila J., Manfred Heiting, and Rachel Stuhlman. Imagining Paradise: the Richard and Ronay Menschel Library at George Eastman House, Rochester. Göttingen: Steidl, 2007.

Hall-Duncan, Nancy. The History of Fashion Photography. New York: Harry N. Abrams, 1978.

Herschdorfer, Nathalie. In Coming into Fashion: A Century of Photography at Condé Nast. Munich: Prestel, 2012.

Mulligan, Therese and David Wooters, eds. A History of Photography: From 1839 to the Present; The George Eastman House Collection. Köln: Taschen, 2005.

Richardson, Diana Edkins ed. Vanity Fair: Photographs of an Age, 1914-1936. New York: Clarkson N. Potter, 1982.

Slide, Anthony. Inside the Hollywood Fan Magazine: A History of Star Makers, Fabricators, and Gossip Mongers. Jackson: University Press of Mississippi, 2010. 